INSTITUTO DE PESQUISAS ENERGÉTICAS E NUCLEARES IPEN-CNEN/SP Autarquia associada à Universidade de São Paulo

\title{
AVALIAÇÃO DO EFEITO RADIOMODIFICADOR DA PRÓPOLIS EM CÉLULAS DE OVÁRIO DE HAMSTER CHINÊS (CHO-K1) E EM CÉLULAS TUMORAIS DE PRÓSTATA (PC3), IRRADIADAS COM CO-60
}

GEYZA SPIGOTI SANTOS

\begin{abstract}
Dissertação apresentada como parte dos requisitos para obtenção do Grau de Mestre em Ciências na área de Tecnologia Nuclear - Aplicações.
\end{abstract}

Orientadora:

Profa. Dra. Kayo Okazaki

São Paulo 
Dedico este trabalho aos meus pais Gilberto e Maria José pelo amor, paciência, confiança, pelos sacrifícios em prol da minha felicidade e apoio em todos os momentos.

A minha irmã pelos momentos felizes e de companheirismo.

Ao meu namorado Marcio, pelo amor, carinho, compreensão e amizade.

Sou eternamente grata a todos vocês. 


\section{AGRADECIMENTOS}

Primeiramente a Deus, por estar sempre orientando meus passos, encorajandome a enfrentar todos os desafios.

À Dra. Kayo Okazaki, meus sinceros agradecimentos pela orientação, oportunidade, paciência, amizade e confiança.

Ao Dr. Paolo Bartolini pela atenção e sugestão dada em todos os momentos.

Ao Dr. Carlos Roberto Jorge Soares, Dra. Teresa Carvalho Pinto Ribela e Dra. Cibele Nunes Peroni pelo apoio, incentivo e ensinamentos compartilhados.

Ao Dr. Daniel Peres, pela realização das análises estatísticas.

À Dra. Márcia Augusta pela amizade que nasceu em meio desta caminhada e por toda ajuda prestada.

Aos meus amigos Beatriz, Fernanda, Miriam, Renata, Eliza, Claudia, Flávia, Vanessa, Danielle, Tamara, Rodrigo, Adilson, Nélio, Marcos, pela amizade, as risadas e os bons momentos que passamos juntos.

Aos amigos Junqueira, José Maria, Dr. João Ezequiel, Dr. Herbert Rodrigues Goulart, Rosângela Arkaten e Arlete Correia pela colaboração e apoio.

À Elizabeth Somessari, Carlos Gaia e Hélio Paes, do Centro de Tecnologia das Radiações (CTR-IPEN), pela disponibilidade para as irradiações das células.

A toda minha família pelo carinho e apoio nos momentos em que mais precisei.

À Família Salgado pelos bons momentos de descontração e felicidade.

Ao Sr. Shigetoshi Tsutsumi Presidente da Empresa Amazon Food Ltd. pela bolsa de estudos concedida.

Ao Instituto de Pesquisas Energéticas e Nucleares, pela oportunidade de realizar este trabalho e pelo auxílio financeiro. 
"O valor das coisas não está no tempo que elas duram, mas na intensidade com que acontecem. Por isso existem momentos inesquecíveis, coisas inexplicáveis e pessoas incomparáveis" (Fernando Sabino). 


\title{
AVALIAÇÃO DO EFEITO RADIOMODIFICADOR DA PRÓPOLIS EM CÉLULAS DE OVÁRIO DE HAMSTER CHINÊS (CHO-K1) E EM CÉLULAS TUMORAIS DE PRÓSTATA (PC3), IRRADIADAS COM CO-60
}

\author{
Geyza Spigoti Santos
}

\section{RESUMO}

Nestas últimas décadas, investigações sobre compostos naturais, efetivos, não tóxicos, com potencial radioprotetor vêm despertando um grande interesse em consonância com a utilização crescente de vários tipos de radiação ionizante nas mais diversas finalidades. Entre eles a própolis uma resina coletada pelas abelhas (Apis mellifera), vem sendo apontada como promissora por apresentar uma série de características biológicas vantajosas, por exemplo, antiinflamatória, antimicrobiana, antitumoral, imunomoduladora, antioxidante e também "scavenger" de radicais livres. O presente estudo teve como objetivo principal, averiguar efeito da própolis brasileira procedente de Rio Grande do Sul (AF 08) em células de ovário de hamster Chinês (CHO-K1) e em células tumorais de próstata (PC3), irradiadas com ${ }^{60} \mathrm{Co}$. Para tanto, foram utilizados três principais parâmetros interligados entre si: indução de micronúcleo, viabilidade celular e morte clonogênica. A escolha destes parâmetros se justifica pelo seu significado biológico, além do fato de serem prontamente observáveis e mensuráveis em células irradiadas. Os dados citogenéticos obtidos, mostraram um efeito radioprotetor da própolis (5 - $100 \mu \mathrm{g} / \mathrm{ml}$ ) na indução de dano ao DNA em ambas as linhagens celulares, irradiadas com doses de 1-4 Gy. No entanto, o ensaio de citotoxicidade mostrou um efeito antiproliferativo pronunciado da própolis (50 $400 \mu \mathrm{g} / \mathrm{ml}$ ) em células PC3 irradiadas com $5 \mathrm{~Gy}$. As curvas de sobrevida obtidas foram ajustadas satisfatoriamente pelo modelo linear-quadrático, cujo componente a foi mais alto em células CHO-K1. Quanto à capacidade clonogênica, as células PC3 mostraram-se mais radiossensíveis que as células 
CHO-K1 nas doses mais altas da curva de sobrevida. A própolis, nas concentrações de $30-100 \mu \mathrm{g} / \mathrm{ml}$, não influenciou no potencial clonogênico das células PC3, visto que, as curvas de sobrevida associadas ou não com a própolis, mostraram perfis similares, ao passo que o tratamento combinado em células CHO-K1 exibiu um efeito estimulador da proliferação. Os dados obtidos in vitro mostraram um potencial uso da própolis AF-08, como uma substância natural e não tóxica, na prevenção contra os efeitos danosos da radiação ionizante, nas doses e nas concentrações analisadas. 


\title{
EVALUATION OF THE RADIOMODIFIER EFFECT OF PRÓPOLIS ON CHINESE HAMSTER OVARY (CHO-K1) AND HUMAN PROSTATE CANCER (PC3) CELLS, IRRADIATED WITH 60-CO
}

\author{
Geyza Spigoti Santos
}

\begin{abstract}
In the last decades, it has been given a great interest to investigations concerning natural, effective, nontoxic compounds with radioprotective potential together with the increasing utilization of different types of ionizing radiation for various applications. Among them propolis, a resinous compound produced by honeybees (Apis mellifera), has been considered quite promising, since it presents several advantageous biological characteristics, i. e., anti-inflammatory, antimicrobial, anticarcinogenic, antioxidant and also free radical scavenging action. The purpose of the present study was to evaluate the effect of Brazilian propolis, collected in the State of Rio Grande do Sul, on Chinese hamster ovary (CHO-K1) and human prostate cancer (PC3) cells, irradiated with ${ }^{60} \mathrm{Co}$ y radiation. For this purpose, three interlinked parameters were analyzed: micronucleus induction, cell viability and clonogenic death. The choice of these parameters was justified by their biological significance, in addition to the fact that they are readily observable and measurable in irradiated cells. The cytogenetic data obtained showed a radioprotective effect of propolis $(5-100 \mu \mathrm{g} / \mathrm{ml})$ in the induction of DNA damage for both cell lines, irradiated with doses of $1-4 \mathrm{~Gy}$. The cytotoxicity assay, however, showed a prominent antiproliferative effect of propolis (50 $400 \mu \mathrm{g} / \mathrm{ml}$ ) in PC3 cells irradiated with $5 \mathrm{~Gy}$. The survival curves obtained were adequately fitted by a linear-quadratic model, where the a coefficient was higher in CHO-K1 cells. Concerning the clonogenic capacity, PC3 cells were more radiosensitive than $\mathrm{CHO}-\mathrm{K} 1$ cells at the higher doses of the survival curve. Propolis at the concentrations of $30-100 \mu \mathrm{g} / \mathrm{ml}$, did not influence the clonogenic potential of PC3 cells, since the survival curves, associated or not with propolis,
\end{abstract}


were found similar, although the combined treatment in CHO-K1 cells exhibited a stimulating proliferative effect. The data obtained in vitro showed a potential use of propolis AF-08, a natural and nontoxic compound, in the prevention against the adverse effect of ionizing radiation, at the doses and concentrations here analyzed. 


\section{SUMÁRIO}

\section{Página}

1 INTRODUÇÃO

1.1 Considerações gerais sobre radioprotetores.........................................12

1.2 Considerações gerais sobre flavonóides e própolis.....................................14

1.3 Considerações gerais sobre ciclo celular e câncer.....................................16

1.3.1 Estratégia geral do ciclo celular......................................................17

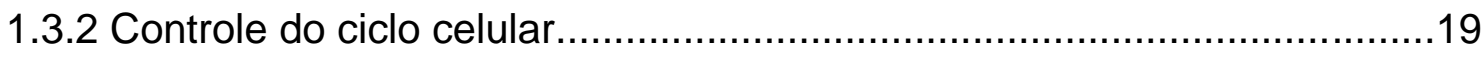

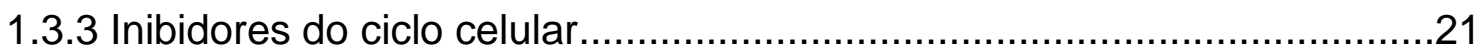

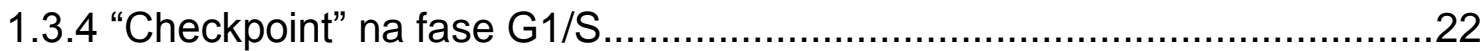

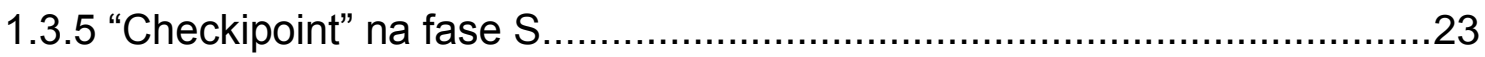

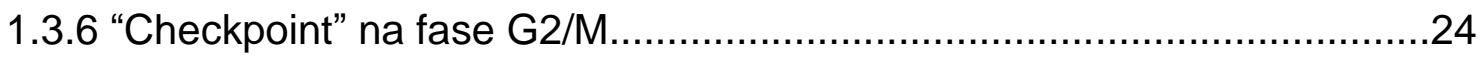

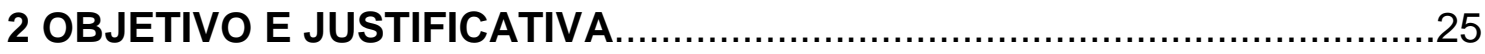

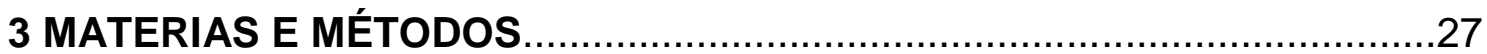

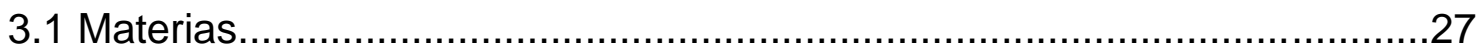

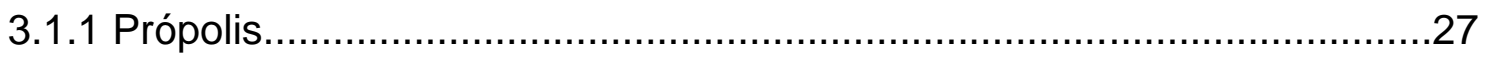

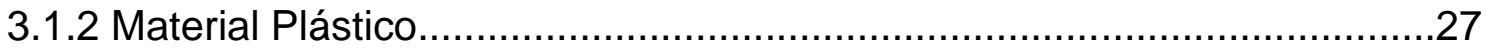

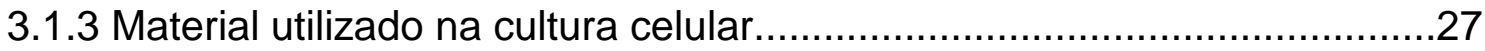

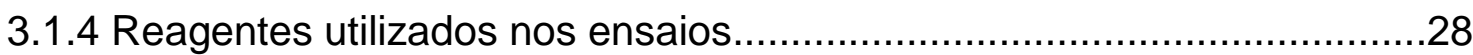

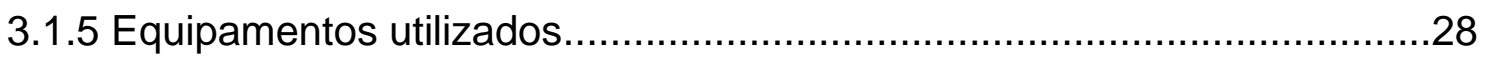

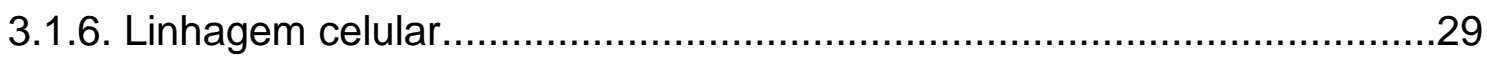

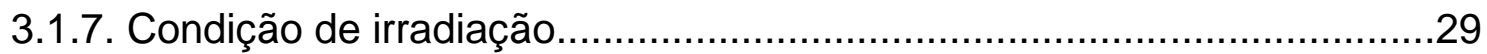

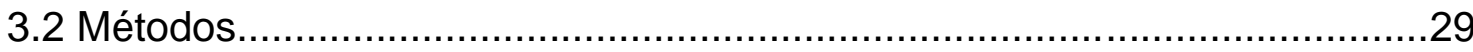

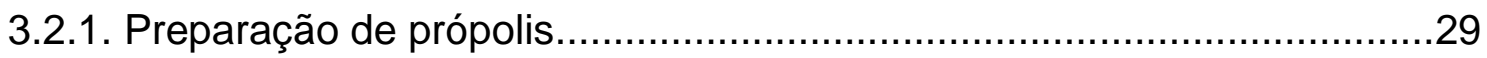

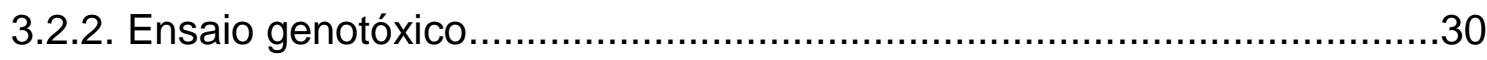


3.2.3 Ensaio citotóxico.

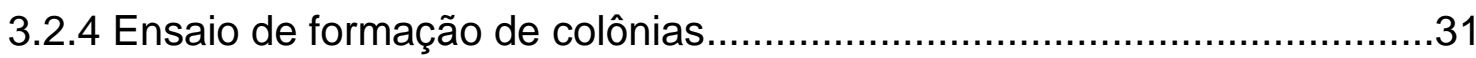

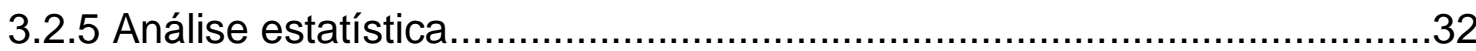

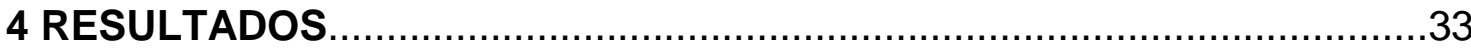

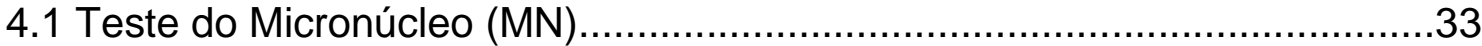

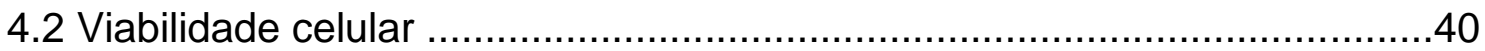

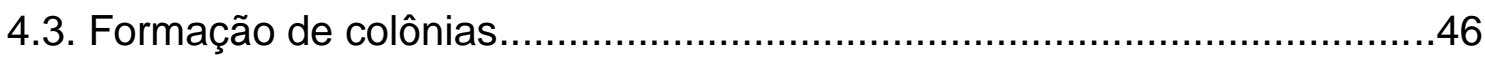

5. DISCUSSÃO

6. CONCLUSÃO

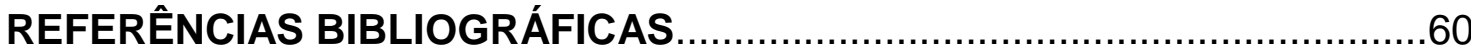




\section{INTRODUÇÃO}

A radiação ionizante é um agente físico que sabidamente afeta células somáticas e germinativas, induzindo mutação, morte celular, malformação e câncer. A intensidade do dano vai depender, entre outros fatores, fundamentalmente, da dose absorvida, do tipo de radiação, das condições de irradiação e da radiossensibilidade intrínseca das células.

Sabe-se, que o dano induzido pela radiação é resultante da deposição de sua energia em células, pela interação direta com as moléculas-alvo da célula (mecanismo direto) ou indiretamente, pela interação com moléculas da água, resultando na produção de radicais livres provenientes da radiólise da água e também pelas espécies reativas de oxigênio $\left(\mathrm{OH} \bullet, 02 \bullet-, \mathrm{H}_{2} \mathrm{O}_{2}\right)$, altamente reativos (mecanismo indireto). Essas interações acarretam várias lesões nas biomoléculas, tais como, DNA, proteínas, carboidratos e lipídeos.

A vida média destes radicais é extremamente curta, da ordem de $10^{-6}$ $10^{-10}$ segundos. Todavia, eles imediatamente reagem com quaisquer biomoléculas da vizinhança e induzem danos oxidativos altamente sítio-específicos. Estima-se que 60 - 70\% do dano tecidual induzido pela radiação ionizante seja causado pelos radicais $\mathrm{OH} \bullet$ (Vijayalaxmi et al., 2004; Jagetia, 2003; Shirazi et al., 2007).

Entre as bases do DNA, guanina é o alvo mais suscetível para reações oxidativas mediadas pelo $\mathrm{OH} \bullet$. Os radicais livres também atacam o esqueleto açúcar-fosfato do DNA, resultando na produção de quebras simples e duplas das fitas, bem como ligações cruzadas DNA-DNA e DNA-proteínas. As quebras nas fitas simples podem ser reparadas rapidamente usando a fita do DNA não danificada como um "template", enquanto que as quebras nas fitas duplas não são facilmente reparáveis e são consideradas as lesões primárias mais significativas sob o ponto radiobiológico, por estarem envolvidas na mutagênese, carcinogênese e teratogênese (Khanna \& Jackson, 2001). 
Além do DNA, os radicais livres gerados pela exposição à radiação ionizante, podem induzir também mudanças na estrutura e função das membranas celulares; Interagem com os sítios insaturados das moléculas de lípídeos das membranas que, por complexas reações em cadeia, resultam na produção de peróxidos lipídicos. Estes alteram as interações hidrofóbicas entre cadeias adjacentes de fosfolípides, permitindo uma penetração mais fácil de moléculas de água, assim alterando a constante dielétrica através da bicamada lipídica que, por sua vez, leva às mudanças na permeabilidade e propriedade das membranas celulares.

Em nível de organismos, exposição de corpo inteiro a doses relativamente altas de radiação ionizante pode desencadear uma série de complexas alterações metabólicas e fisiológicas como náusea, vômito, diarréia, fadiga, febre, queda de cabelos, alterações sanguíneas, letargia e convulsões. Este conjunto de sintomas característicos é conhecido como síndrome da radiação ionizante e didaticamente é classificada em hematopoiética, gastrointestinal e do sistema nervoso central, dependendo fundamentalmente da dose absorvida e do tempo que leva à morte (Hall, 2000). A extensão do dano produzido pela radiação ionizante só foi avaliada mais detalhadamente após a II Guerra Mundial, sendo então reconhecida a necessidade de proteção contra esses efeitos.

Assim sendo, tentativas para minimizar a radiotoxicidade imposta às células/tecidos em casos de exposição acidental ou ocupacional, tem propiciado estudos objetivando na identificação de compostos capazes de conferir proteção contra danos da radiação ionizante.

\subsection{Considerações gerais sobre radioprotetores}

A busca por agentes protetores ideais direcionados a vários cenários de exposição à radiação perdura há mais de seis décadas. Pelo fato do dano celular ser atribuído primariamente aos efeitos maléficos dos radicais livres, moléculas com propriedades de neutralizar estes radicais são consideradas particularmente promissoras como radioprotetoras. Uma série de substâncias tem sido apontada a 
conferir proteção contra efeitos adversos da radiação ionizante. De modo geral, o mecanismo de ação da maioria destas substâncias é via "scavenging" de radicais livres produzidos pela radiação. Levando-se em consideração a vida extremamente curta dos radicais livres, estes agentes necessitariam estar presentes no meio celular, preferencialmente, antes da exposição à radiação para neutralizar as propriedades destrutivas dos radicais livres (Hosseinimehr, 2007; Vijayalaxmi et al., 2007). A habilidade de certas substâncias de fornecer proteção contra efeitos danificantes da radiação ionizante foi primeiramente documentada em 1949 (Dale et al., 1949). Os radioprotetores melhor conhecidos são os compostos aminotióis, como cisteína, cisteamina e AET (brometo de 2-aminoetilisotiuréia) (Hall, 2000; Weiss \& Landauer, 2009).

Com os efeitos devastadores das bombas detonadas em Hiroshima e Nagasaki, vividos nos anos após a Segunda Guerra Mundial, iniciou-se um programa no final da década de 1950 pelo exército dos EUA. De 1959 a 1973, o Instituto de Pesquisas Walter Reed sintetizou e testou > 4000 compostos numa tentativa de encontrar um radioprotetor promissor que pudesse proteger contra efeitos agudos e tardios da radiação ionizante sem efeitos tóxicos colaterais (Vijayalaxmi et al., 2004). O mais efetivo composto deste tipo, originalmente testado contra doses letais de raios $X$ e gama em camundongos foi o WR2721 [ácido S-2-(3 aminopropilamino) etilfosforotioico] também chamado de amifostine (Yuhas, 1983). O WR2721 foi um dos poucos agentes aprovados pela Administração de Alimentos e Drogas dos EUA (FDA), para prevenção de xerostomia induzida pela irradiação, em 1995. Entre outros agentes aprovados pelo FDA constam Azul de Prússia, Ca-DTPA, Zn-DTPA e iodeto de potássio para uso na redução de toxicidade causada pela contaminação interna de radionuclídeos (iodo, plutônio, urânio, césio) em casos de exposição acidental ou ocupacional (Hosseinimehr, 2007; Weiss \& Landauer, 2009). Embora a amifostine tenha sido reportada como bem tolerada em clínica radioterápica, posteriormente foram constatados vários efeitos colaterais indesejáveis, que incluem hipotensão, náusea, vômito, sonolência, e hipocalcemia. Estes efeitos colaterais são severos suficientes para limitar a quantidade de droga necessária para níveis mais baixos para encontrar radioproteção máxima. Além do mais, WR 2721 é efetivo somente quando administrado intravenosa ou subcutaneamente, o que limita a sua 
utilização fora das situações clínicas controladas. Assim, há necessidade para identificar compostos não tóxicos, efetivos e convenientes para proteção humana dos efeitos adversos da radiação ionizante. Uma série de compostos tem sido testada para a sua eficácia radioprotetora. Todavia, todos esses compostos produzem efeitos colaterais indesejáveis, como náusea e vômitos e são considerados tóxicos nas doses necessárias para a radioproteção, o que limita o seu uso na prática médica (Vijayalaxmi et al., 2004; Shirazi et al., 2007).

Tendo em vista que muitos compostos sintéticos testados apresentam um sucesso limitado, substâncias com propriedades antioxidantes que ocorrem naturalmente, como enzimas endógenas (glutationa, superóxido dismutase, catalase) ou hormônios (melatonina), vitaminas (vitaminas C e E), carotenóides e fitoquímicos (flavonóides, curcumina), têm despertado um interesse particular cada vez maior (Weiss \& Landauer, 2009).

\subsection{Considerações gerais sobre flavonóides e própolis}

Os flavonóides representam uma classe de pigmentos encontrados nas plantas, derivados de benzo- $\gamma$-pirona, que nos últimos anos tem sido objeto de considerável interesse científico e terapêutico (Havsteen, 2002). Muita atenção dada aos compostos flavonóides é devido aos resultados obtidos de estudos epidemiológicos que têm mostrado uma associação direta entre o consumo de frutas/ vegetais e o risco diminuído de vários tipos de câncer, incluindo o de mama, colon, laringe, pâncreas e próstata (Ross \& Kasum, 2002; Rithidech et al., 2005). Esses possíveis efeitos protetores de flavonóides, juntamente com suas atividades antioxidativas e "scavenger" de radicais livres, observados tanto em estudos in vivo (Orsolic et al., 2007; Benkovic et al., 2008a) como in vitro (Benkovic et al., 2008b), tem propiciado um interesse público sobre o consumo de flavonóides para seus potenciais benefícios à saúde.

Desde que a concentração fisiológica de flavonóides nos vegetais de modo geral é baixa e a sua extração é laboriosa, uma alternativa atrativa tem sido o uso de própolis que contém uma concentração mais alta de flavonóides, cerca de $25-30$ \% do seu peso seco (Krol et al., 1990; Benkovic et al., 2008b). Uma 
amostra típica de própolis contém cerca de 25 diferentes flavonóides em concentrações significativas, o que sugere que o extrato de própolis retém a maioria das propriedades bioquímicas comumente associadas aos flavonóides, isto é, efeito antioxidante e "scavenging" de radicais (Havsteen, 2002).

A própolis é uma resina de coloração amarelo-marrom e de consistência variada, coletada e elaborada por abelhas (Apis mellifera), de diversas partes das plantas e é utilizada pelas abelhas para selar eventuais aberturas na colméia e para eliminar possíveis invasores. A palavra própolis vem dos termos gregos "pro" (em defesa de) e "polis" (cidade). Isso implica em um produto envolvido na defesa da colméia. Dentre os produtos apícolas, a própolis, que vem sendo usada em medicina popular por séculos, vem se destacando tanto pelas suas propriedades terapêuticas como atividades antimicrobiana (Daugsch et al., 2007), anti-inflamatória, antioxidante, imunoestimuladora, cicatrizante, anestésica e anti-carcinogênica (Park et al., 1998; Park \& Ikegaki, 1998), quanto pela possibilidade de aplicação nas indústrias farmacêuticas e alimentícias.

Mais de 300 compostos têm sido identificados em própolis (Ishihara et al., 2009). Produtos da própolis originários da Europa e China contêm vários tipos de flavonóides e esters de ácido fenólico (CAPE), enquanto que a própolis brasileira é composta principalmente de artepilina C (ácido 3,5-diprenil-4hidroxicinamico), terpenóides e ácido p-cumárico (Chen et al., 2004). A artepilina C é conhecida por apresentar atividades antitumoral, antioxidante, imunomoduladora e indutora de apoptose em vários tipos de carcinomas (Kimoto et al., 2001; Shimizu et al., 2005; Pisco et al., 2006; Ishihara et al., 2009). Uma tentativa de classificar a própolis produzida no Brasil de acordo com a sua composição química, baseada nas suas características físico-químicas reconheceu 12 tipos: cinco delas ocorrem na região sul, um no sudeste e seis no nordeste do Brasil (Park et al., 2002; Daugsch et al., 2007; Li et al., 2007).

A própolis brasileira tem como principais fontes botânicas, Baccharis dracunculifolia (Alecrim), Eucalyptus citriodora, Araucaria angustifólia, Hyptis divaricata, Populus nigra, Dalbergia ecastophyllum (Kumazawa et al., 2003, 2007; Búfalo et al., 2007; Daugsch et al., 2007) e não apresenta CAPE, mas contém especificamente artepilina C, da ordem de $40 \%$ de peso no extrato fenólico 
(Shimizu et al., 2005). No entanto, a própolis procedente da região sul do Brasil não contém artepilina $C$ na sua composição, mas é relativamente rica em flavonóides, incluindo galangina, apigenina, crisina, pinobanksina, pinobanksina-3 e pinocembrina (Li et al., 2007). A principal origem botânica da própolis dessa região foi identificada como sendo Myrceugenia eurosma (Myrtaceae), um cultivo abundante no sul do Brasil, quase na fronteira com o Uruguai (Ito et al., 2001).

Esta diferença na origem vegetal pode acarretar diferentes composições químicas e diferentes quantidades de compostos ativos que, consequentemente, podem influenciar às atividades biológicas da própolis. No entanto, fatores como a ecologia da região onde a própolis é coletada e até mesmo a variabilidade genética das abelhas rainhas influenciam à composição química da própolis e, por conseguinte, a sua atividade biológica (Park et al., 2002; Park et al., 2004). Dessa forma, estudos visando a identificação da fonte vegetal e caracterização de compostos biologicamente ativos da própolis associadas às suas atividades biológicas e terapêuticas, têm recebido uma atenção especial nestes últimos anos (Daugsch et al., 2007).

Estudos mostram que certos flavonóides como apigenina, quercetina e genisteina exibem atividades biológicas e anti-tumorais, induzindo bloqueio do ciclo celular em vários tipos celulares (McVean et al., 2002; Vermeulen et al., 2003; Rithidech et al., 2005).

\subsection{Considerações gerais sobre ciclo celular e câncer}

O câncer é o resultado de acúmulo de alterações genéticas e epigenéticas que envolvem genes que, direta ou indiretamente, controlam importantes funções biológicas como proliferação e morte celulares. No câncer, há alterações fundamentais no controle genético da divisão celular, resultando na proliferação celular inadequada. As mutações ocorrem, principalmente, envolvendo duas classes de genes: proto-oncogenes e genes supressores tumorais. Em células normais, os produtos dos proto-oncogenes agem nos diferentes níveis ao longo das rotas bioquímicas que estimulam a proliferação celular. Versões mutadas de proto-oncogenes ou oncogenes podem promover o 
crescimento tumoral. Inativação de genes supressores tumorais como pRb e p53, resulta na disfunção de proteínas que normalmente inibem a progressão do ciclo celular. Desregulação do ciclo celular associada ao câncer ocorre através de mutações de proteínas importantes nos diferentes níveis do ciclo celular. Nos cânceres, mutações têm sido observadas nos genes que codificam kinases dependentes de ciclina (CDK), ciclinas, enzimas ativadoras de CDK, proteínas do "checkpoint", entre outros (Vermeulen et al., 2003).

Segundo dados do Instituto Nacional do Câncer (INCA, 2010), o carcinoma de próstata representa a segunda causa de morte entre homens no mundo inteiro, inclusive no Brasil, depois do câncer de pele não melanoma. A despeito do seu grande impacto, a etiologia do câncer de próstata e os fatores que promovem a sua progressão tumoral ainda não são conhecidos. $O$ tratamento para carcinoma de próstata localizado, geralmente, incluem radioterapia externa, braquiterapia prostática, prostatectomia radical e hormonioterapia. A radioterapia externa é efetiva para tumores localizados. $O$ tratamento geralmente se estende por 7 - 8 semanas com dose total de 65 - 75 Gy, com fração de dose em torno de 1,8 - 2 Gy (Scott et al., 2004). Todavia, a recorrência e a metástase de câncer de próstata, constituem os maiores problemas da terapia. Atualmente, os tratamentos disponíveis apresentam efeitos colaterais como à incontinência urinária e a disfunção erétil. Não há modalidade de tratamento eficaz, uma vez que o câncer evolui para o estágio refratário ao hormônio (Moraes et al., 2010).

\subsubsection{Estratégia geral do ciclo celular}

O evento central da proliferação celular é o ciclo de divisão celular, um processo pelo qual uma célula cresce, replica o seu DNA e então se divide para dar origem às duas células-filhas. Este processo é dividido em quatro fases seqüenciais: G1, S, G2 e mitose (M). A fase $S$ e a fase de mitose, onde ocorrem, respectivamente, a duplicação do material genético e a distribuição equitativa de DNA para as duas células-filhas, são consideradas etapas cruciais da célula. A replicação do DNA não pode iniciar até que a mitose seja completada e a mitose não pode começar até que a rodada prévia da replicação do DNA seja terminada e, dessa maneira, a integridade do genoma é mantida. Há, também, um quinto 
estado, GO (conhecido como fase de "repouso"), em que a célula pode reversivelmente sair do $\mathrm{G} 1$, destituída de sinais apropriados de crescimento. $A$ maioria das células não proliferativas do corpo humano se encontra no estado G0 (Garrett, 2001).

A transição de uma fase à outra do ciclo celular, ocorre de maneira ordenada e é regulada por uma série de diferentes proteínas que atuam nos pontos estratégicos do ciclo celular, conhecidos como "checkpoints". Hartwell \& Weinert (1989), primeiramente, definiram o termo "checkpoint" do ciclo celular, como sendo um mecanismo que mantém a ordem dos eventos de cada ciclo celular. Em outras palavras, "checkpoints" são mecanismos sensores da célula que monitoram o ambiente celular e determinam se as condições são adequadas antes de prosseguir através do ciclo de divisão celular. Consequentemente, a principal função destes "checkpoints" é a de verificar se a integridade do genoma permanece intacta através do ciclo celular. Cada "checkpoint" é executado por meio de três componentes. O primeiro é um mecanismo sensor que detecta eventos incompletos ou aberrantes do ciclo celular, como dano no DNA. Este evento é seguido por uma rota de transdução de sinais que é transmitido do sensor ao terceiro componente, o efetor que pode determinar o bloqueio do ciclo celular para permitir tempo suficiente para reparar o dano induzido. O primeiro "checkpoint" ocorre na fase de transição G1/S e é o principal sensor do dano do DNA. O próximo vem do "checkpoint" G2/M, que monitora a fidelidade da replicação do DNA e, como o "checkpont" G1/S, é um importante sensor do dano no DNA. Este é seguido pelo "checkpoint" mitótico, que está envolvido durante a mitose e averigua se há fuso mitótico funcional que não tenha sido corretamente formado (Vermeulen et al., 2003).

Há ainda, o ponto de restrição $R$, que ocorre entre o meio e o final do G1. Este é o ponto no qual, a célula averigua se tem recebido sinais de crescimento necessários (geralmente de origem extracelular) e assim que pode passar de G1 para S, replicar o seu DNA e completar uma rodada de divisão celular. Se, todavia, a célula não tem recebido estímulos suficientes, ela não passará do ponto de restrição e em vez disso, entrará no GO. Este ponto de restrição, portanto, difere de outros "checkpoints" por não determinar 
especificamente a integridade do genoma. Se estes "checkpoints" do ciclo celular são bloqueados, então podem propiciar uma proliferação celular inadequada, o que eventualmente podem levar à indução tumoral. Provavelmente, todos os tumores humanos carregam alterações genéticas tanto nos genes que controlam a progressão do ciclo celular como nos genes que controlam a função do "checkpoint".

\subsubsection{Controle do ciclo celular}

Em células de mamíferos, as proteínas reguladoras chaves do ciclo celular são as kinases dependentes de ciclina (CDK) (subunidade catalítica), uma família de proteína kinase serina/treonina que são ativadas nos pontos específicos do ciclo celular. O nome CDK descreve o fato de que toda a atividade dessas kinases é dependente da sua associação com a subunidade reguladora conhecida como ciclina (subunidade reguladora). Até agora, nove CDK tem sido identificados e destes, cinco são ativos durante o ciclo celular, isto é, durante G1 (CDK4, CDK6 e CDK2), S (CDK2), G2 e M (CDK1) (Figura 1).

Quando ativados, os CDK induzem processos coordenados pela fosforilação de proteínas específicas. Níveis de CDK permanecem estáveis durante o ciclo celular, em contraste às suas proteínas ativadas, as ciclinas que são dependentes do ciclo celular.

Assim, um CDK específico terá toda a atividade quando a sua parceira ciclina é expressa. O papel dos CDKs é o de controlar a progressão do ciclo celular através da fosforilação das proteínas que funcionam nos estágios específicos do ciclo celular. (Figura 2). 


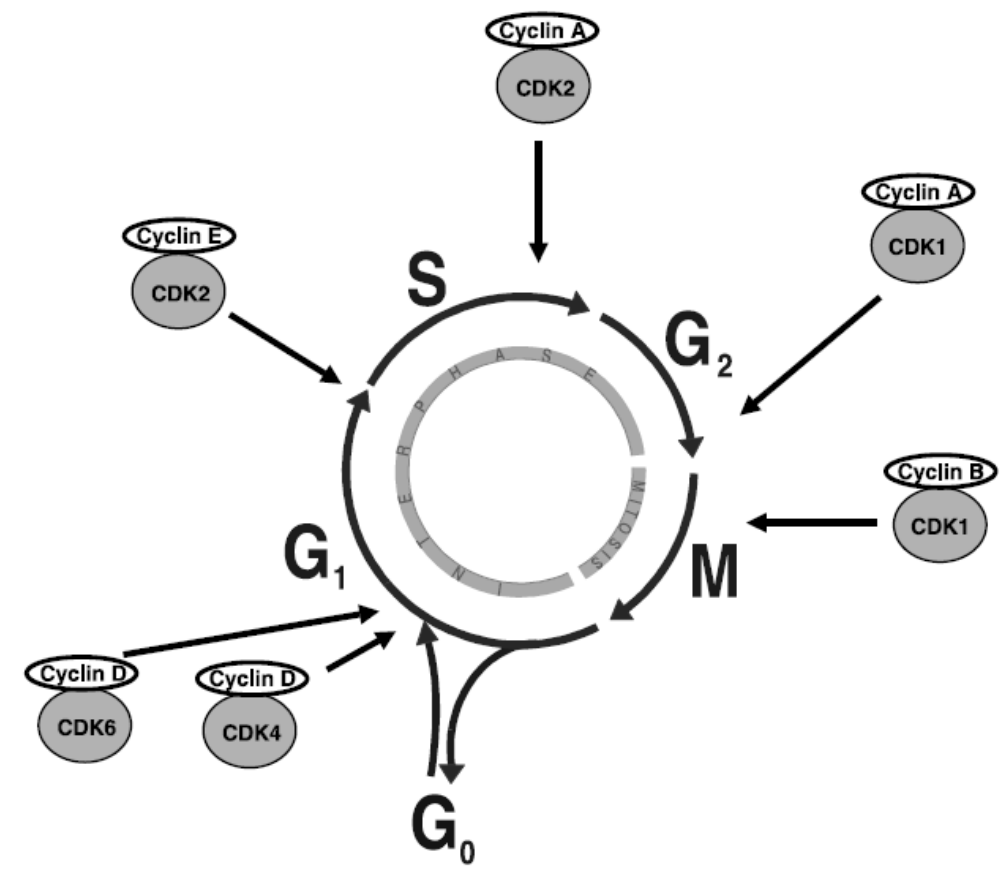

FIGURA 1: Etapas do ciclo celular, indicando sítios de atividades dos complexos regulatórios CDK/Ciclina (Vermeulen et al., 2003).

Os níveis da ciclina aumentam e diminuem durante o ciclo celular e desta maneira, elas ativam periodicamente CDK. Diferentes ciclinas são necessárias para diferentes fases do ciclo celular. As 3 ciclinas do tipo D (ciclina D1, ciclina D2, ciclina D3) se ligam a CDK4 e CDK6 e os complexos CDK-ciclina D são essenciais para entrar no G1 (Figura 2). Diferente de outras ciclinas, a ciclina $D$ não é expressa periodicamente, mas é sintetizada assim que a estimulação pelo fator de crescimento persiste. Uma outra ciclina G1 é a ciclina $E$ que se associa ao CDK2 para regular a progressão de G1 para $S$. A ciclina A se liga ao CDK2 e este complexo é necessário durante a fase S. No G2 tardio e na mitose precoce, a ciclina A forma complexo com CDK1 para promover a entrada para mitose. A mitose é posteriormente regulada pela ciclina $B$, formando complexo com CDK1. Dezesseis ciclinas têm sido identificadas, mas como o CDK, nem todas elas estão relacionadas com o ciclo celular. As ciclinas são posteriormente destruídas pela proteólise mediada pela ubiquitina, no final da cada fase do ciclo celular (Garret, 2001; Vermeulen et al., 2003). 


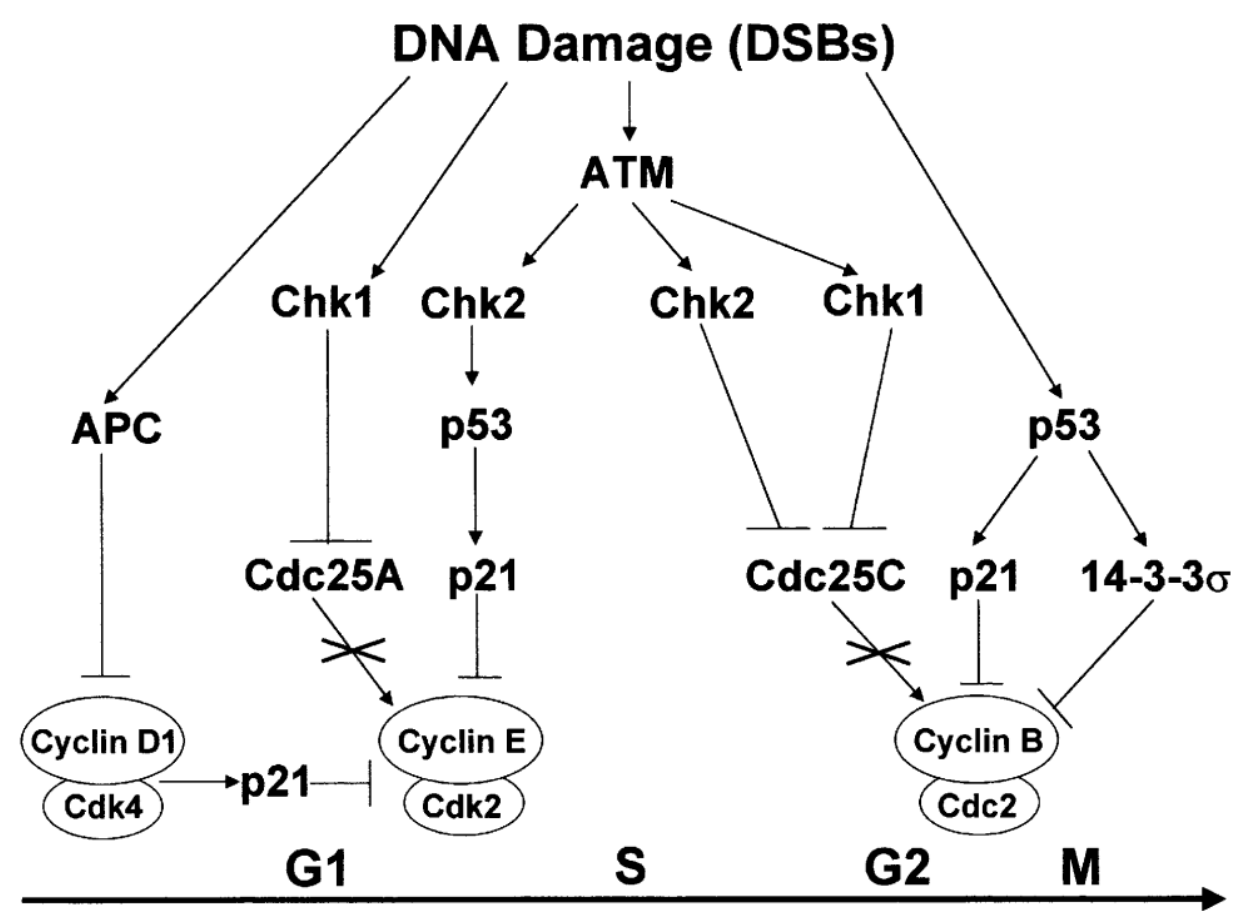

FIGURA 2: "Checkpoints" G1/S e G2/M em resposta ao dano no DNA (Garrett, 2001).

\subsubsection{Inibidores do ciclo celular}

Duas famílias de proteínas inibidoras do ciclo celular foram identificadas, chamadas inibidoras do CDK (CKI) que se ligam ao CDK sozinhas ou formando complexo CDK-ciclina e inibem as atividades do CDK. A primeira identificada foi a família INK4 (Inibidores de CDK4) e a outra, a família Cip/Kip (CDK Interacting Protein/Kinase Inhibitory Protein). A família INK4 inclui p15, p16, p18, p19, que especificamente inativa CDK G1 (CDK4 e CDK6). Estes CK1 formam complexos estáveis com a enzima CDK antes da ligação com ciclina, prevenindo associação com a ciclina D. A segunda família de inibidores, a família Cip/Kip inclui p21, p27, p57. Estes inibidores inativam complexos CDK G1-ciclina e em menor extensão, CDK1-ciclina B. O p21 também inibe síntese de DNA pelo "binding" e inibição do antígeno nuclear de proliferação celular (PCNA). Os CKI são regulados pelos sinais internos e externos: a expressão do p21 é dependente do controle transcripcional do p53. O promotor do gene p21 contém um sítio de ligação com p53 que permite ao p53 ativar transcripcionalemte o p21. 
A expressão e a ativação, respectivamente, p15 e p27, aumentam em resposta ao fator de crescimento $\beta$ transformante (TGF- $\beta$ ), contribuindo no bloqueio do crescimento.

Embora muitos estresses celulares podem estar envolvidos nos "checkpoints" do ciclo celular (hipóxia, privação de soro, dano no DNA), as rotas de "checkpoints" para transição G1/S e G2/M são aquelas que estão envolvidas na resposta ao dano no DNA, causado pelas quebras nas fitas duplas do DNA (DSBs). Este tipo de dano no DNA podem ser induzidos por uma série de agentes dos quais a radiação ionizante, genotóxicos químicos e espécies reativas de $\mathrm{O}_{2}$ são os principais responsáveis.

\subsection{4 "Checkpoint" na fase G1/S}

O "checkpoint" no G1/S é mediado pela ação do produto do gene supressor tumoral conhecido como p53 (Figura 2).

Perda da função de p53, como resultado de mutações no gene, o que pode eventualmente levar à indução tumoral, elimina o "checkpoint" no G1/S. O gene p53 é mutado ou deletado em mais de $50 \%$ de todos os cânceres esporádicos, constituindo o mais comum defeito em tumor humano. Uma explicação para isto é o papel que o produto deste gene representa como "Guardião do Genoma". A proteina p53 executa esta função agindo como um receptor de sinais de estresse (incluindo dano no DNA) que causa ativação e acúmulo de proteína p53 na célula. O p53 é rapidamente induzido em resposta ao DNA danificado. Uma série de kinases, fosfatases, histona acetilases e enzimas conjugadas a ubiquitina regulam a estabilidade do p53 bem como a sua atividade de transcrição após o dano no DNA. O p53, um fator de transcrição, é uma proteína de vida curta que é mantida nos níveis baixos em células normais pela sua ligação com Mdm2, um regulador negativo de p53. O Mdm2 é uma ligase de ubiquitina E3 que promove a ubiquitinação do p53 e exporta do núcleo para degradação proteolítica no citoplasma. Um exemplo de complexo regulatório, p53 e Mdm2, é fosforilado pelo ATM, uma proteína kinase chave na ativação dos "checkpoints" do ciclo celular, em células com DNA danificado. O gene ATM é 
responsável pela desordem autossômica recessiva, conhecida como ataxia telangectasia (AT), caracterizada pela degeneração neuronal progressiva, deficiência imunológica, alta radiossensibilidade e um risco aumentado ao câncer.

A fosforilação dependente de ATM modula a atividade transcripcional do p53 e a fosforilação de Mdm2 mediada pelo ATM, diminuindo a habilidade do Mdm2 de transportar p53 do núcleo para o citoplasma para a sua degradação, o que resulta no acúmulo nuclear e estabilização de p53 em resposta ao agente. Isto permite ao p53 induzir uma série de genes transcripcionalmente, incluindo inibidor de CDK, o p21, que inibe CDK2, cuja atividade é necessária para a progressão de $\mathrm{G} 1$ para $\mathrm{S}$, assim, causando um bloqueio no G1/S. No caso de células severamente danificadas, o p53 induz morte celular pela ativação de genes (Bax, Fas e genes envolvidos nas rotas de estresse oxidativo) que estão envolvidos na sinalização da apoptose.

Uma rota adicional, independente de p53 é também ativada pelo ATM para impedir a progressão para a fase $S$, em resposta ao dano no DNA. O principal alvo do ATM nesta rota é o Chk2, que é fosforilado nos múltiplos resíduos de serina/treonina, incluindo sítio regulatório na treonina 68 pelo ATM em resposta à quebra na fita dupla do DNA. A conseqüência desta forforilação é a estimulação da atividade do Chk2 e a fosforilação do seu alvo, Cdc25A. Este evento de fosforilação estimula a degradação do Cdc25A que bloqueia a entrada para S após o dano induzido, impedindo a defosforilação/ativação do CDK2, dependente de Cdc25A (Khanna \& Chenevis-Trench, 2004).

\subsection{5 "Checkpoint" na fase S}

Os mecanismos do "checkpoint" do dano no DNA na fase S são pouco compreendidos. Alguns estudos demonstram que a taxa de síntese do DNA é mais lenta e em contraste ao "checkpoint" no G1/S, parece não haver um bloqueio completo, prolongando a fase $S$. Isto tem levado a sugerir que o "checkpoint" na fase $S$, resultante de dano no DNA, não bloqueia totalmente a replicação do DNA. Há evidência também de que a fosforilação do NBS1, mediada pelo ATM, é necessária para induzir bloqueio na fase S. Em células de mamíferos, 4 proteínas 
foram identificadas, envolvidas neste "checkpoint". Estas são, a proteína kinase ATM, Nibrina (ou NBS1), uma proteína de reparo da DSB que é mutada em síndrome de Nijimegen (NBS), Mrell que é mutada em desordem parecida com AT e Rad50 (Garret, 2001; Khanna \& Chenevix-Trench, 2004).

\subsection{6 "Checkpoint" na fase G2/M}

O "checkpoint" no G2/M ao dano no DNA envolve vários componentes que participam do "checkpoint" no G1/S (Figura 2). Todavia, o seu alvo não é o Cdk2/ciclina $E$, mas sim o complexo Cdc2/ciclina B, que é necessário para a progressão do G2 para a mitose. Consequentemente, a principal função do "checkpoint" é a de manter o complexo Cdc2/ciclina B1 inativo.

Quando o dano no DNA ocorre durante a fase G2, as células são capazes de iniciar um bloqueio do ciclo celular na presença ou na ausência do p53 (Vermeulen et al., 2003). A progressão para a mitose é impedida pela manutenção do CDK na sua forma inibida, através da fosforilação inibitória ou pelo seqüestro de componentes do complexo CDK1-ciclina B para fora do núcleo.

Essa inibição são executadas pelas proteínas kinases Chk e Chk2, que são ativadas quando ocorre o dano no DNA, de maneira dependente de ATM e que fosforilam Cdc25. Fosforilação de Cdc25 inibe as suas atividades e se associa a proteína 14-3-3, que transporta o Cdc25 para fora do núcleo, impedindo assim de ativar CDK1-ciclina $\mathrm{B}$ e, consequentemente, a entrada para a mitose. Além da indução de fosforilação inibitória do CDK, o p53 pode também representar um papel na regulação do "checkpoint" no G2/M. Aumento da expressão do p53 dependente do dano no DNA resulta, como ocorre durante o "checkopoint" no G1/S, no aumento de transcrição do p21 e da sigma14-3-3. Porém, a proteína 14-3-6 sigma não se liga ao Cdc25, e em vez disso, se liga a ciclina $B$ e seqüestra o complexo ciclina $B / C D K 1$ para fora no núcleo. $O$ p53 também intervém na dissociação do complexo CDK1-ciclina B1 pela indução de Gadd45 (gene indutível pelo dano no DNA). Finalmente, o "checkpoint" mitótico detecta se há ou não o alinhamento impróprio dos cromossomos no fuso mitótico e em caso positivo, pára o ciclo celular na metáfase da mitose (Vermeulen et al., 2003). 


\section{OBJETIVO E JUSTIFICATIVA}

Tendo em vista que vários compostos químicos sintetizados e testados quanto à eficácia radioprotetora apresentam efeitos colaterais tóxicos, justifica-se a necessidade de buscar substâncias naturais, não tóxicas, com propriedades radioprotetoras e de fácil obtenção, que possam proporcionar melhores estratégias para proteção ou prevenção contra exposição genotóxica ambiental.

Uma vez que a composição química da própolis varia de acordo com a ecologia local, há necessidade, além da caracterização qualitativa e quantitativa dos componentes da própolis, averiguar também a eficácia biológica da própolis de diferentes procedências. A despeito do amplo espectro de atividades da própolis e da sua reconhecida importância à saúde humana, há poucas informações na literatura sobre a própolis brasileira, especificamente, própolis proveniente da região sul do Brasil. Para o nosso conhecimento, somente três trabalhos foram publicados no que se refere a própolis procedente de Rio Grande do Sul: Ito et al. (2001) verificaram uma atividade anti-HIV significativa da própolis em cultura de linfócitos H9; Li et al. (2007) observaram uma atividade antiproliferativa do extrato etanólico de própolis, no crescimento de células do tumor primário bem como do metastático da próstata; Shimizu et al.(2008) descreveram atividade antiviral de influenza pela própolis da região sul (AF-08) em modelo animal.

O presente estudo teve como objetivo principal, averiguar a influência do extrato etanólico de própolis procedente de Rio Grande do Sul (AF-08), Brasil, contra danos genotóxicos, citotóxicos e morte clonogênica, induzidos pela radiação gama de ${ }^{60} \mathrm{Co}$, em células de ovário de hamster Chinês $(\mathrm{CHO}-\mathrm{K} 1)$ e em células tumorais humanas de próstata (PC3). A escolha de $\mathrm{CHO}-\mathrm{K} 1$ como objeto de estudo reside no fato desta linhagem celular, ser amplamente utilizada como células-referência nos ensaios de genotoxicidade e citotoxicidade, entre outros, por apresentar uma série de características vantajosas inerentes: pertence a uma linhagem celular geneticamente estabelecida, capaz de formar colônias nos 
substratos, tem uma taxa de crescimento relativamente rápida com cariótipo relativamente estável de $22 \pm 2$ cromossomos (Murakami et al., 2004). As células PC3 pertencem a uma linhagem tumoral metastática humana de próstata, crescem bem em condições in vitro e cuja incidência deste tipo de câncer é relativamente alta, acometendo uma parcela significativa da população masculina.

A avaliação genotóxica foi feita em nível cromossômico pela análise da indução de micronúcleos, resultantes de danos não reparados, especificamente, quebras ocorridas nas fitas duplas do DNA, potencialmente carcinogênicas. A avaliação citotóxica foi feita pela análise da viabilidade celular e a capacidade clonogênica por meio do teste clássico de formação de colônias. A escolha desses parâmetros se justifica pelo seu significado biológico, além de serem prontamente observáveis e mensuráveis em células irradiadas. 


\section{MATERIAS E MÉTODOS}

\subsection{Materiais}

\subsubsection{Própolis}

- Foi utilizada própolis (AF-08) procedente do Estado de Rio Grande do Sul, Brasil.

\subsubsection{Material Plástico}

- Garrafas de $75 \mathrm{~cm}^{2}$, CORNING COSTAR CORP. (NY, EUA)

- Pipetas de 2, 5, 10 e $25 \mathrm{~mL}$, CORNING COSTAR CORP. (NY, EUA)

- Placas de 6 poços, CORNING COSTAR CORP. (NY, EUA)

- Placas de 24 poços, CORNING COSTAR CORP. (NY, EUA)

- Placas de 96 poços, CORNING COSTAR CORP. (NY, EUA)

- Sistema de Filtração de $500 \mathrm{~mL}, 0,22 \mu \mathrm{m}$, CORNING COSTAR CORP. (NY, EUA)

- Tubos criogênicos de $2 \mathrm{~mL}$, CORNING COSTAR CORP. (NY, EUA)

- Tubos para centrífuga de 15 e $50 \mathrm{~mL}$, CORNING COSTAR CORP. (NY, EUA)

- Tubos cônicos com tampa de 1,5 mL, Eppendorf (Hamburgo, Alemanha)

\subsubsection{Material utilizado na cultura celular}

- Ácido etilenodiaminotetracético (EDTA), LABSYNTH (São Paulo, SP, Brasil)

- Dimetilsufóxido (DMSO), MERK (São Paulo, SP, Brasil)

- Meio RPMI 1640, GIBCO-BRL (Gaithersburg, MD, EUA)

- Penicilina, estreptomicina, GIBCO-BRL (Gaithersburg, MD, EUA)

- Soro fetal bovino (SFB), GIBCO-BRL (Gaithersburg, MD, EUA)

- Tripsina, GIBCO-BRL (Gaithersburg, MD, EUA) 


\subsubsection{Reagentes utilizados nos ensaios}

- Citocalasina - B (St. Louis, MO, EUA)

- Ácido acético, MERK (São Paulo, SP, Brasil)

- Formaldeído, MERK (São Paulo, SP, Brasil)

- Metanol, MERK (São Paulo, SP, Brasil)

- Fosfato monobásico de potássio $\left(\mathrm{KH}_{2} \mathrm{PO}_{4}\right)$, LABSYNTH (São Paulo, SP, Brasil)

- Fosfato monohidratado dibásico de sódio $\left(\mathrm{Na}_{2} \mathrm{HPO}_{4} \mathrm{H}_{2} \mathrm{O}\right)$, LABSYNTH (São Paulo, SP, Brasil)

- Giemsa, BERSE (São Paulo, SP, Brasil)

- Glicerina, MERCK (São Paulo, SP, Brasil)

- Metanol, MERCK (São Paulo, SP, Brasil)

- MTS, PROMEGA CORPORATION (Madison, WI, EUA)

- PMS, SIGMA (St. Louis, MO, EUA)

\subsubsection{Equipamentos utilizados}

- Autoclave de mesa, série 2100, KAVOKLAVE (São Paulo, SP, Brasil)

- Banho-maria, modelo 100, FANEN (São Paulo, SP, Brasil)

- Centrífuga de bancada, modelo LS 3 plus , CELM (São Paulo, SP, Brasil)

- Estufa para cultura de células, 3159, FORMA SCIENTIFIC (Marietta, OH, EUA)

- Fluxo laminar vertical classe II A/B3, 1140, FORMA SCIENTIFIC (Marietta, $\mathrm{OH}, \mathrm{EUA})$

- Microscópio óptico, CARL ZEISS (Oberkochen, Alemanha)

- Microscópio óptico, NIKON Eclipse 80i (Nikon Corporation, Japão)

- Microscópio invertido, ID 03, CARL ZEISS (Oberkochen, Alemanha)

- Purificador de água, Milli-Q-plus, MILLIPORE (Bedford, MA, EUA)

- Sistema de estocagem de criotubos em nitrogênio líquido, Locator Junior, THERMOLYNE (Dubuque, IA, EUA)

- Sistema de estocagem de criotubos, $1^{\circ} \mathrm{C}$ Freezing container, NALGENE COMPANY (Rochester, NY EUA) 


\subsubsection{Linhagem celular}

Foram utilizadas células $\mathrm{CHO}-\mathrm{K} 1$, subclone de células ovarianas de hamster Chinês (Cricetulus griseus) e células PC3, originárias de metástase óssea de próstata (adenocarcinoma metastático humano). As células $\mathrm{CHO}-\mathrm{K} 1$ apresentam duração do ciclo celular de 12-14h (Dean \& Danford, 1984), enquanto que as células PC3, de $\sim 34 \mathrm{~h}$ (Scott et al., 2004). Ambas as células foram mantidas em meio RPMI 1640 (Cultilab) suplementado com 10\% de soro fetal bovino (Gibco) com $1 \%$ de penicilina e estreptomicina (Sigma), incubadas a $37^{\circ} \mathrm{C}$ na presença de $5 \%$ de $\mathrm{CO}_{2}$.

\subsubsection{Condição de irradiação}

Tanto células $\mathrm{CHO}-\mathrm{K} 1$ como PC3 foram acondicionadas em tubos Eppendorf e irradiadas numa fonte de ${ }^{60} \mathrm{Co}$ (Gammacell 220, Irradiation Unit of Canadian Atomic Energy Commission, Ltd) ( 2,82 Gy/min), nas doses de 1 - 6 Gy a temperatura ambiente. Toda a irradiação das células foi feita no Centro de Tecnológia das Radiações (CTR - IPEN / CNEN - SP).

\subsection{Métodos}

\subsubsection{Preparação de própolis}

A própolis bruta foi preparada conforme descrita por Li et al. (2007) com algumas modificações. Aproximadamente, $100 \mathrm{~g}$ de própolis foram tratadas com $200 \mathrm{ml}$ de etanol 95\% durante 6 meses. A seguir, a mistura foi filtrada e mantida no freezer por $24 \mathrm{~h}$, passando em seguida pela segunda filtração (extrato etanólico).

Posteriormente, o extrato etanólico assim obtido foi submetido à evaporação, obtendo-se um extrato resinoso (AF-08). Foi preparada uma soluçãomãe na concentração de $1 \mathrm{mg} / \mathrm{ml}$ (10\% DMSO + 90\% de água destilada), mantida a $4^{\circ} \mathrm{C}$. Antes do uso, o extrato etanólico foi filtrado no Millipore $(0,22 \mu \mathrm{m})$. 


\subsubsection{Ensaio genotóxico}

\section{Teste do micronúcleo (MN)}

Para a avaliação citogenética de danos induzidos no DNA foi adotado o método do bloqueio citocinético (Fenech \& Morley, 1986) utilizando a citocalasina $\mathrm{B}$ para a obtenção de células binucleadas. As células na fase exponencial de crescimento foram semeadas em placas de 6 wells e após 48h de adesão, foram incubadas por $1 \mathrm{~h}$ com diferentes concentrações de própolis $(5,10,15,30,50$ e $100 \mu \mathrm{g} / \mathrm{ml}$ ) e então irradiadas com ${ }^{60} \mathrm{Co}$, nas doses de 1, 2 e 4 Gy. O tempo de incubação de $1 \mathrm{~h}$ antes da irradiação foi baseado nos dados da literatura (Rao et al., 2006). Após as irradiações, as células foram semeadas em placa de Petri com $60 \mathrm{~mm}$ de diâmetro contendo meio, soro, antibiótico e citocalasina B (3 $\mu \mathrm{g} / \mathrm{ml})$, mantidas por 48 e $72 \mathrm{~h}$ para células $\mathrm{CHO}-\mathrm{K} 1$ e $\mathrm{PC} 3$, respectivamente, a $37^{\circ} \mathrm{C}$ com $5 \%$ de $\mathrm{CO}_{2}$. A seguir, as células foram tripsinizadas, transferidas para tubos Falcon de $15 \mathrm{ml}$, tratadas com solução isotônica ( $\mathrm{NaCl}$ 0,85\%) e fixadas com ácido acético e metanol (1:3). As suspensões celulares foram gotejadas em lâminas histológicas e fixadas a $65^{\circ} \mathrm{C}$ numa atmosfera úmida e coradas com Giemsa a $10 \%$ em tampão fosfato $\mathrm{pH}$ 6,8 por 10 minutos. Os MN foram identificados segundo critério adotado pela AIEA (2001): os MN foram contados somente em células com citoplasma preservado, no mesmo plano focal, não confluentes do núcleo principal, com diâmetro de até $1 / 3$ e com a mesma coloração do núcleo principal (Figura 3). Foram consideradas células binuecleadas contendo até $5 \mathrm{MN}$. Dois parâmetros foram levados em consideração: incidência de células atingidas pela radiação (\% de células binucleadas com MN) e intensidade de dano intracelular ( $n^{\circ}$ de MN/célula). As lâminas foram analisadas no micorcópio óptico (Carl Zeiss) no aumento de $400 \mathrm{X}$. Para cada amostra, cerca de 500 células binucleadas foram contadas para 3 ensaios independentes. Todas as células mono e multinucleadas acompanhantes foram computadas. 


\subsubsection{Ensaio citotóxico}

\section{Viabilidade celular}

Para a avaliação da viabilidade celular foi adotado o método colorimétrico utilizando MTS e PMS (Promega, Madison, WI). O ensaio consiste, basicamente, em determinar o número de células vivas através da capacidade que elas têm em converter o composto MTS (tetrazolium 3-(4,5-dimetiltiazol-2-yl)5-(3-carboxi-metoxifenil)-2-(4-sulfofenil)-2H-tetrazolium) na presença do PMS (metossulfeto de ferazina) em um produto formazan, solúvel em meio de cultura, graças às enzimas desidrogenases presentes nas mitocôndrias de células metabolicamente ativas ou vivas. A quantidade de produto formazan formado é determinada pela absorbância a $490 \mathrm{~nm}$ e é proporcional ao número de células viáveis em cultura. Para tanto, as células foram incubadas com diferentes concentrações de própolis $(50,100,200$ e $400 \mu \mathrm{g} / \mathrm{ml})$ por 1 ou 24h, antes da irradiação com 5 Gy de ${ }^{60} \mathrm{Co}$. A escolha do tempo de incubação de $24 \mathrm{~h}$ foi baseada nos dados da literatura (Chen et al., 2004). A seguir, as células foram semeadas em placa de 96 poços, contendo $2,5 \times 10^{3}$ células num volume final de $100 \mu \mathrm{l} /$ poço, mantidas por $72 \mathrm{~h}$ a $37^{\circ} \mathrm{C}$ com $5 \%$ de $\mathrm{CO}_{2}$. A densidade celular foi determinada, adicionando $20 \mu \mathrm{l} /$ poço de solução composta de MTS $(2 \mathrm{mg} / \mathrm{ml}$ de PBS) e PMS (0,92 mg/ml de PBS), na proporção de 19:1, cuja absorbância foi lida a $490 \mathrm{~nm}$ no leitor de ELISA, 1h após a adição do corante. Cada amostra de própolis foi feita em quadriplicata. Os valores de absorbância obtidos foram convertidos em \% de viabilidade celular, com 100\% representando células controle, sem própolis e sem irradiação.

\subsubsection{Ensaio de formação de colônias}

\section{Curva de sobrevida}

Para a avaliação do potencial clonogênico, tanto células $\mathrm{CHO}-\mathrm{K} 1$ como PC3 foram incubadas com diferentes concentrações de própolis (30, 50 e 100 $\mu \mathrm{g} / \mathrm{ml}$ ) durante $24 \mathrm{~h}$ a $37^{\circ} \mathrm{C}$ com $5 \%$ de $\mathrm{CO}_{2}$. A seguir, as células foram irradiadas com 1, 2, 4 e 6 Gy de ${ }^{60}$ Co e semeadas (200 - 300 células/placa) em placa de Petri com $60 \mathrm{~mm}$ de diâmetro, mantidas a $37^{\circ} \mathrm{C}$. Cada amostra foi feita em 
triplicata. Após 10 - 14 dias de semeadura, o meio foi removido e as células foram lavadas com PBS, fixadas com formol a $1 \%$ por 30 minutos e coradas com Giemsa a 20 \% em tampão fosfato, pH 6,8 por 30 minutos. As colônias formadas para cada placa foram analisadas no contador de colônias CP 600 (Phoenix). Colônias contendo $<50$ células foram desprezadas. Os resultados foram expressos em eficiência de plaqueamento (EP) e fração de sobrevida (FS) de acordo com Hall (2000):

$$
E P=\left(n^{\circ} \text { de colônias contadas }\right) /\left(n^{\circ} \text { de células semeadas }\right) \times 100
$$

$\mathrm{FS}=\mathrm{n}^{0}$ de colônias contadas em cultura tratada $/ \mathrm{n}^{0}$ de células semeadas) $X($ EP em cultura controle/100)

\subsubsection{Análise estatística}

Toda a análise foi feita usando o programa GraphPad Prism (versão 5.0) para a elaboração de gráficos e tabelas. Para comparação de dados obtidos entre diferentes tratamentos foi utilizado ANOVA two-way. Valor de $p<0,05$ foi considerado estatisticamente significativo. As curvas de sobrevida de células tratadas com própolis e irradiadas foram ajustadas pelo modelo exponencial quadrático, $Y=e^{-\alpha D-\beta D 2}$, onde $Y$ é a $F S$, $\alpha$ e $\beta$ são constantes do modelo e $D$ é a dose absorvida em Gy. 


\section{RESULTADOS}

\subsection{Teste do Micronúcleo (MN)}

A figura 3 mostra a presença de $\mathrm{MN}$ em células binucleadas de $\mathrm{CHO}$ $\mathrm{K} 1$ e PC3, tratadas com citocalasina B.

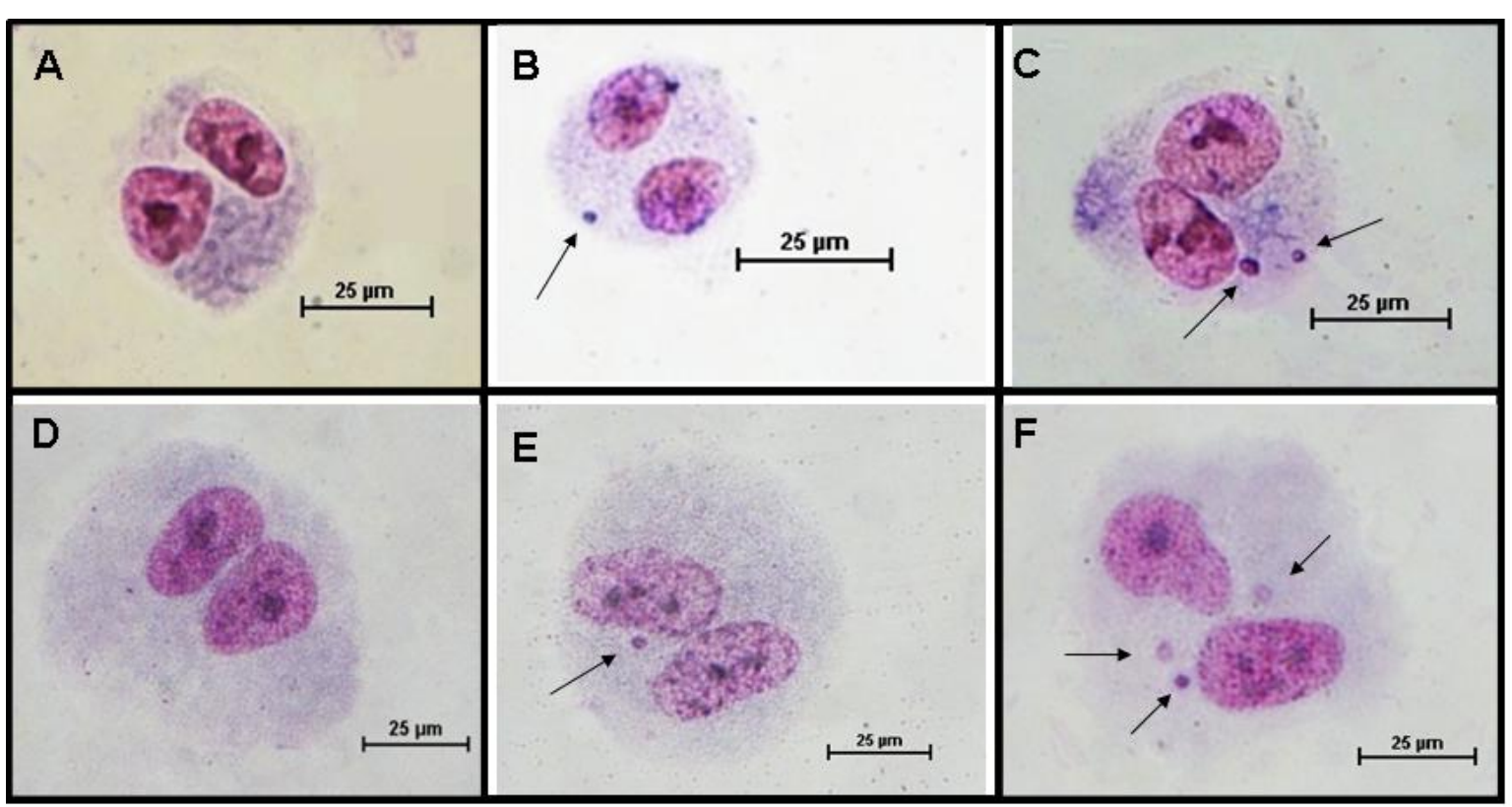

Figura 3: Micrografias de células binucleadas de CHO-K1 (A,B,C) e PC3 (D,E,F). A e D) sem micronúcleo; B e E ) com 1 micronúcleo; C) com 2 micronúcleos; F) com 3 micronúcleos.

As tabelas 1 e 2 mostram dados citogenéticos obtidos de células $\mathrm{CHO}$ $\mathrm{K} 1$ e PC3, tratadas com própolis e irradiadas.

Uma representação gráfica em forma de histograma para os dois

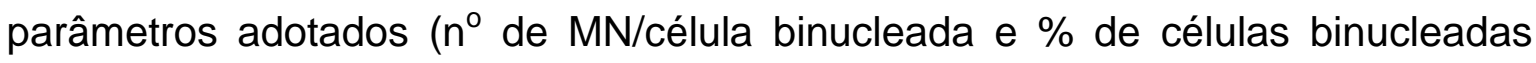
com MN) está expressa nas Figuras 4 e 5. 
TABELA 1 (A): Frequência e distribuição de micronúcleos (MN) em células binucleadas (CB) de CHO-K1 tratadas com própolis $(5,10,15$ e $30 \mu \mathrm{g} / \mathrm{mL})$ e irradiadas com 1 Gy de ${ }^{60} \mathrm{Co}(\mathrm{N}=3)$.

\begin{tabular}{|c|c|c|c|c|c|c|}
\hline $\begin{array}{c}\text { Amostra } \\
\text { Concentração } \\
\text { de própolis } \\
(\mu \mathrm{g} / \mathrm{ml})\end{array}$ & $\begin{array}{c}\text { Total de } \\
\text { CB } \\
\text { analisadas }\end{array}$ & CB & om & 3 & MN/CB & $\begin{array}{c}\% \text { CB com } \\
\text { MN } \\
\text { (média } \pm d p \text { ) }\end{array}$ \\
\hline Controle & 1559 & 17 & 4 & 0 & $25(0,016 \pm 0,003)$ & $21(1,3 \pm 0,2)$ \\
\hline 5 & 1737 & 17 & 3 & 0 & $23(0,013 \pm 0,003)$ & $20(1,1 \pm 0,2)$ \\
\hline 10 & 1413 & 10 & 0 & 0 & $10(0,007 \pm 0,005)$ & $10(0,7 \pm 0,5)$ \\
\hline 15 & 1630 & 15 & 2 & 0 & $19(0,012 \pm 0,004)$ & $17(1,0 \pm 0,3)$ \\
\hline 30 & 1586 & 23 & 0 & 0 & $23(0,014 \pm 0,005)$ & $23(1,4 \pm 0,5)$ \\
\hline $1 \mathrm{~Gy}$ & 1638 & 67 & 5 & 0 & $77(0,047 \pm 0,016)$ & $72(4,4 \pm 1,3)$ \\
\hline 5+1Gy & 1551 & 47 & 3 & 0 & $53(0,034 \pm 0,005)$ & $50(3,2 \pm 0,7)$ \\
\hline 10+1Gy & 1592 & 46 & 2 & 0 & $50(0,031 \pm 0,021)$ & $48(3,0 \pm 1,9)$ \\
\hline 15+1Gy & 1558 & 39 & 2 & 0 & $43(0,028 \pm 0,023)$ & $41(2,6 \pm 2,1)$ \\
\hline $30+1 G y$ & 1541 & 26 & 1 & 0 & $28(0,018 \pm 0,008)$ & $27(1,7 \pm 0,9)$ \\
\hline
\end{tabular}


TABELA 1 (B): Frequência e distribuição de micronúcleos (MN) em células binucleadas (CB) de PC3, tratadas com própolis $(5,10,15$ e $30 \mu \mathrm{g} / \mathrm{mL})$ e irradiadas com 1 Gy de ${ }^{60} \mathrm{Co}(\mathrm{N}=3)$.

\begin{tabular}{|c|c|c|c|c|c|c|}
\hline $\begin{array}{c}\text { Amostra } \\
\text { Concentração } \\
\text { de própolis } \\
(\mu \mathrm{g} / \mathrm{ml})\end{array}$ & $\begin{array}{c}\text { Total de } \\
\text { CB } \\
\text { analisadas }\end{array}$ & CB & com & $\mathbf{M N}$ & $\begin{array}{c}\text { MN/CB } \\
\text { (média } \pm d p)\end{array}$ & $\begin{array}{c}\% \text { CB com } \\
\text { MN } \\
\text { (média } \pm d p \text { ) }\end{array}$ \\
\hline Controle & 1732 & 54 & 6 & 3 & $75(0,043 \pm 0,008)$ & $63(3,6 \pm 0,7)$ \\
\hline 5 & 1599 & 38 & 5 & 0 & $48(0,030 \pm 0,009)$ & $43(2,7 \pm 0,5)$ \\
\hline 10 & 1630 & 36 & 4 & 3 & $53(0,033 \pm 0,009)$ & $43(2,6 \pm 0,8)$ \\
\hline 15 & 1615 & 47 & 0 & 1 & $50(0,031 \pm 0,012)$ & $48(3,0 \pm 1,2)$ \\
\hline 30 & 1614 & 38 & 8 & 0 & $54(0,033 \pm 0,004)$ & $46(2,8 \pm 0,3)$ \\
\hline $1 \mathrm{~Gy}$ & 1642 & 75 & 13 & 2 & $107(0,065 \pm 0,016)$ & $90(5,5 \pm 1,1)$ \\
\hline 5+1Gy & 1605 & 46 & 6 & 1 & $61(0,038 \pm 0,003)$ & $53(3,3 \pm 0,5)$ \\
\hline $10+1 G y$ & 1679 & 37 & 5 & 0 & $47(0,028 \pm 0,006)$ & $42(2,5 \pm 0,6)$ \\
\hline $15+1 G y$ & 1597 & 43 & 5 & 0 & $53(0,033 \pm 0,006)$ & $48(3,0 \pm 0,6)$ \\
\hline $30+1 \mathrm{~Gy}$ & 1635 & 46 & 9 & 1 & $67(0,041 \pm 0,004)$ & $56(3,4 \pm 0,3)$ \\
\hline
\end{tabular}


TABELA 2 (A): Frequência e distribuição de micronúcleos (MN) em células binucleadas (CB) de CHO-K1, tratadas com própolis (50 e $100 \mu \mathrm{g} / \mathrm{mL}$ ) e irradiadas com 1, 2 e 4 Gy de ${ }^{60}$ Co $(\mathrm{N}=3)$.

\begin{tabular}{|c|c|c|c|c|c|c|c|c|}
\hline $\begin{array}{c}\text { Amostra } \\
\text { Concentração } \\
\text { de própolis } \\
(\mu \mathrm{g} / \mathrm{ml})\end{array}$ & $\begin{array}{c}\text { Total de } \\
\text { CB } \\
\text { analisadas }\end{array}$ & 1 & CB & com & MN & 5 & (média $\pm d p)$ & $\begin{array}{c}\% \text { CB com } \\
\text { MN } \\
\text { (média } \pm d p \text { ) }\end{array}$ \\
\hline Controle & 1631 & 38 & 4 & 0 & 0 & 0 & $46(0,028 \pm 0,009)$ & $42(2,6 \pm 0,8)$ \\
\hline 50 & 1633 & 30 & 2 & 0 & 0 & 0 & $34(0,021 \pm 0,007)$ & $32(1,9 \pm 0,6)$ \\
\hline 100 & 1588 & 20 & 1 & 1 & 0 & 0 & $25(0,016 \pm 0,010)$ & $22(1,4 \pm 0,6)$ \\
\hline $1 \mathrm{~Gy}$ & 1595 & 46 & 4 & 1 & 0 & 0 & $57(0,036 \pm 0,012)$ & $51(3,2 \pm 1,2)$ \\
\hline 2 Gy & 1659 & 127 & 9 & 1 & 0 & 0 & $148(0,089 \pm 0,047)$ & $137(8,2 \pm 4,1)$ \\
\hline 4 Gy & 1742 & 199 & 19 & 3 & 0 & 0 & $246(0,141 \pm 0,086)$ & $221(12,7 \pm 7,7)$ \\
\hline $50+1 G y$ & 1552 & 42 & 1 & 0 & 0 & 0 & $44(0,028 \pm 0,015)$ & $43(2,8 \pm 1,4)$ \\
\hline $100+1 G y$ & 1816 & 27 & 3 & 0 & 0 & 0 & $33(0,018 \pm 0,010)$ & $30(1,6 \pm 0,8)$ \\
\hline $50+2 G y$ & 1689 & 90 & 5 & 0 & 1 & 0 & $104(0,061 \pm 0,040)$ & $96(5,7 \pm 4,0)$ \\
\hline $100+2 G y$ & 1612 & 85 & 2 & 0 & 0 & 0 & $89(0,055 \pm 0,041)$ & $87(5,4 \pm 3,9)$ \\
\hline $50+4 G y$ & 2057 & 201 & 32 & 2 & 0 & 1 & $276(0,134 \pm 0,085)$ & $236(11,5 \pm 7,9)$ \\
\hline $100+4 G y$ & 1990 & 186 & 18 & 2 & 0 & 0 & $228(0,114 \pm 0,082)$ & $206(10,3 \pm 7,3)$ \\
\hline
\end{tabular}


TABELA 2 (B): Frequência e distribuição de micronúcleos (MN) em células binucleadas (CB) de PC3, tratadas com própolis (50 e $100 \mu \mathrm{g} / \mathrm{mL}$ ) e irradiadas com 1, 2 e 4 Gy de ${ }^{60} \mathrm{Co}(\mathrm{N}=3)$.

\begin{tabular}{|c|c|c|c|c|c|c|c|c|}
\hline $\begin{array}{c}\text { Amostra } \\
\text { Concentração } \\
\text { de própolis } \\
(\mu \mathrm{g} / \mathrm{ml})\end{array}$ & $\begin{array}{c}\text { Total de } \\
\text { CB } \\
\text { analisadas }\end{array}$ & 1 & CB & on & MN & 5 & (média $\pm d p)$ & $\begin{array}{c}\% \text { CB com } \\
\text { MN } \\
\text { (média } \pm d p \text { ) }\end{array}$ \\
\hline Controle & 1666 & 69 & 6 & 1 & 0 & 0 & $84(0,050 \pm 0,007)$ & $76(4,6 \pm 0,6)$ \\
\hline 50 & 1605 & 55 & 6 & 1 & 0 & 0 & $70(0,044 \pm 0,008)$ & $62(3,9 \pm 0,4)$ \\
\hline 100 & 1599 & 49 & 5 & 1 & 1 & 0 & $66(0,041 \pm 0,004)$ & $56(3,5 \pm 0,4)$ \\
\hline $1 \mathrm{~Gy}$ & 1743 & 115 & 21 & 0 & 1 & 0 & $161(0,092 \pm 0,032)$ & $137(7,9 \pm 2,7)$ \\
\hline 2 Gy & 1718 & 142 & 21 & 5 & 0 & 0 & $199(0,116 \pm 0,029)$ & $168(9,8 \pm 2,4)$ \\
\hline 4 Gy & 1800 & 195 & 41 & 8 & 2 & 0 & $309(0,172 \pm 0,072)$ & $246(13,7 \pm 5,4)$ \\
\hline $50+1 G y$ & 1617 & 83 & 13 & 0 & 1 & 0 & $113(0,070 \pm 0,034)$ & $97(6,0 \pm 2,7)$ \\
\hline $100+1 G y$ & 1721 & 71 & 8 & 1 & 0 & 0 & $90(0,052 \pm 0,002)$ & $80(4,6 \pm 0,4)$ \\
\hline $50+2 G y$ & 1635 & 74 & 5 & 1 & 0 & 0 & $87(0,053 \pm 0,022)$ & $80(4,9 \pm 2,2)$ \\
\hline $100+2 G y$ & 1710 & 69 & 9 & 1 & 0 & 0 & $90(0,053 \pm 0,021)$ & $79(4,6 \pm 1,9)$ \\
\hline $50+4 G y$ & 1647 & 119 & 10 & 3 & 1 & 0 & $152(0,092 \pm 0,053)$ & $133(8,1 \pm 4,3)$ \\
\hline $100+4 G y$ & 1756 & 122 & 13 & 3 & 0 & 0 & $157(0,089 \pm 0,051)$ & $138(7,8 \pm 4,5)$ \\
\hline
\end{tabular}


A
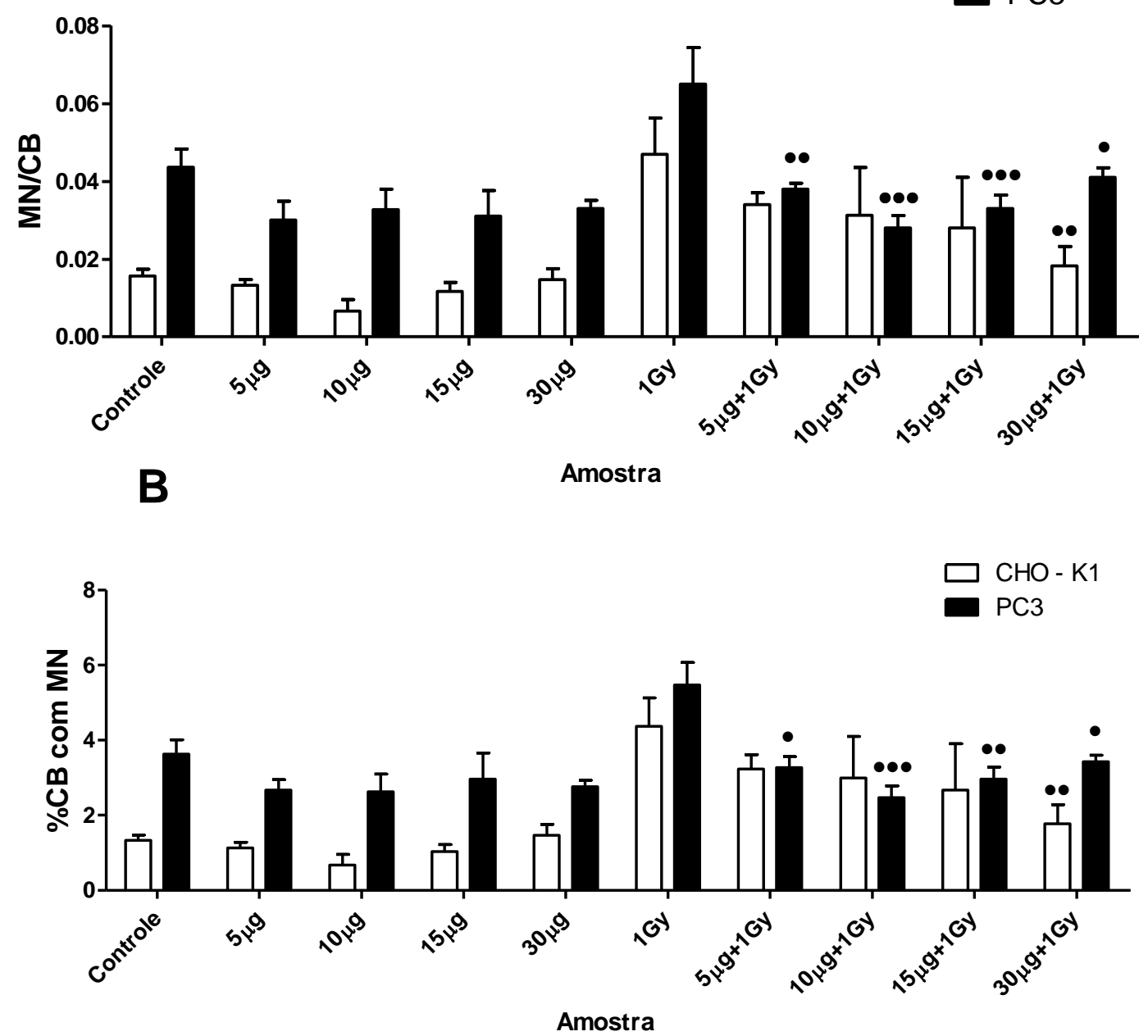

FIGURA 4: Frequências de micronúcleos (MN) observadas em células binucleadas (CB) de $\mathrm{CHO}-\mathrm{K} 1$ e PC3, tratadas com diferentes concentrações de própolis $(5-30 \mu \mathrm{g} / \mathrm{mL})$ e irradiadas com $1 \mathrm{~Gy}$ de ${ }^{60} \mathrm{Co}$. A) Numero de MN por célula binucleada. B) Porcentagem de células binucleadas com $M N$. Controle $=$ sem própolis e sem irradiação. $\bullet p<0,05$, $\bullet p<0,01, \bullet \bullet p<0,001$. 
A

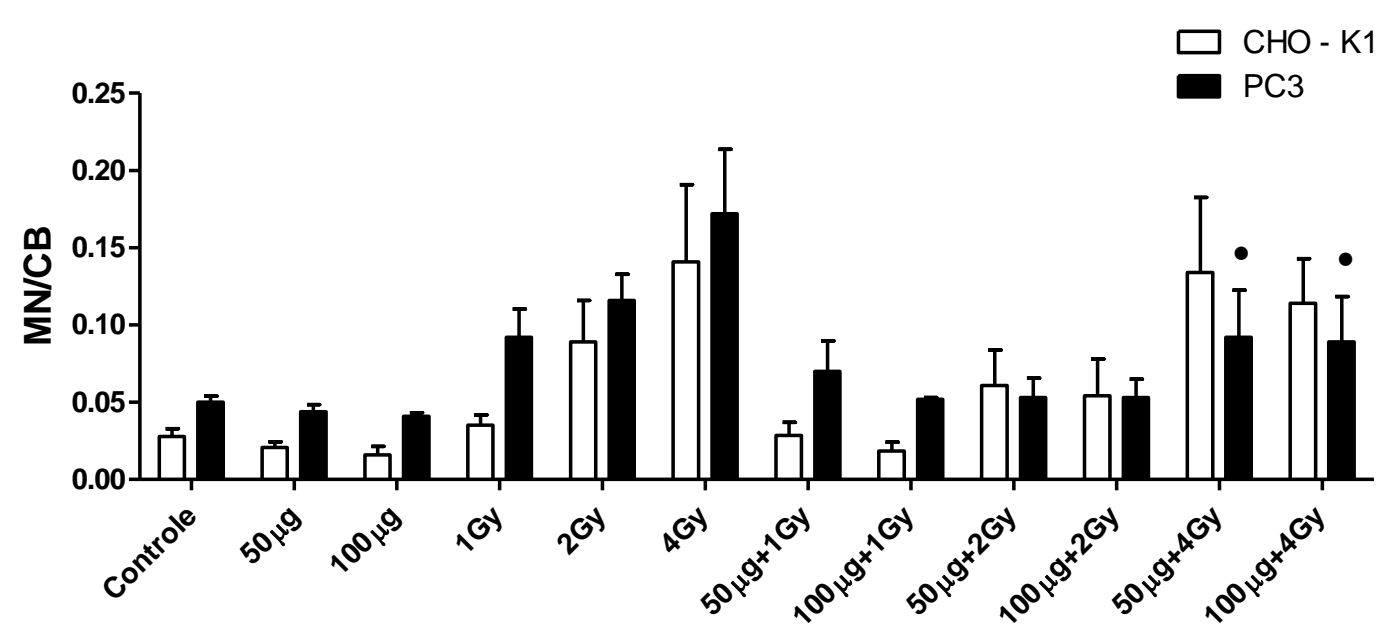

B

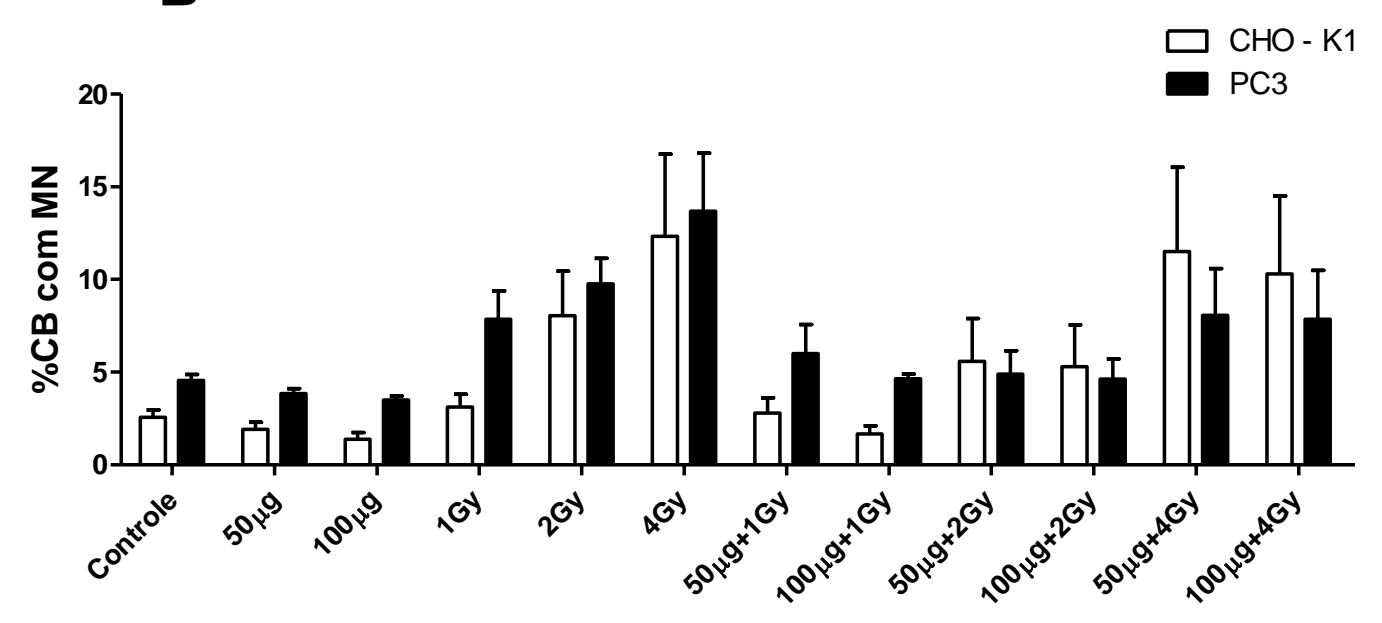

Amostra

FIGURA 5: Frequências de micronúcleos (MN) observadas em células binucleadas (CB) de $\mathrm{CHO}-\mathrm{K} 1$ e PC3, tratadas com 50 e $100 \mu \mathrm{g} / \mathrm{mL}$ de própolis e irradiadas com 1, 2 e 4 Gy de ${ }^{60} \mathrm{Co}$. A) Numero de MN por célula binucleada. B) Porcentagem de células binucleadas com MN. Controle = sem própolis e sem irradiação. $\bullet p<0,05$.

Pode observar que a própolis per se não induziu qualquer efeito genotóxico, pelo menos nas concentrações testadas $(p>0,05)$ em ambas as linhagens celulares. As células PC3 mostraram uma quantidade maior de danos basais que as células $\mathrm{CHO}-\mathrm{K} 1$. 
Ressalta-se que as duas linhagens celulares submetidas ao tratamento combinado com a própolis + radiação, apresentaram dano genotóxico menor que àquelas somente irradiadas, tanto nas concentrações mais baixas $(5-30 \mu \mathrm{g} / \mathrm{ml})$ associadas a 1 Gy de ${ }^{60} \mathrm{Co}$ (Figura $4 \mathrm{~A}$ e B) como nas mais altas (50 e $100 \mu \mathrm{g} / \mathrm{ml}$ ) associadas a doses mais altas de 2 e 4 Gy (Figura 5 A e B).

Houve uma tendência à queda na quantidade de dano ao DNA em função da concentração de própolis. Todavia, em células CHO-K1, a análise estatística (ANOVA two-way) mostrou significância somente na concentração de $30 \mu \mathrm{g} / \mathrm{ml}$ associada com $1 \mathrm{~Gy}$, nos 2 parâmetros analisados. Em células PC3, no entanto, a diferença foi significativa para todas as concentrações de própolis (5 $30 \mu \mathrm{g} / \mathrm{ml}$ ), associadas com 1 Gy de ${ }^{60} \mathrm{Co}$. Para concentrações mais altas de própolis (50 e $100 \mu \mathrm{g} / \mathrm{ml}$ ) (Figura $5 \mathrm{~A}$ e B), a análise estatística mostrou não significância dos tratamentos nas 2 linhagens, exceto para células PC3 irradiadas com 4 Gy, quando levou-se em consideração o grau de dano/célula.

\subsection{Viabilidade celular}

Os dados obtidos sobre o efeito da própolis na citotoxicidade de células submetidas às diferentes concentrações de própolis por 1 e $24 \mathrm{~h}$ antes da irradiação, estão apresentados nas Tabelas 3 e 4, para células CHO-K1 e PC3, respectivamente. 
TABELA 3: Valores de viabilidade (\%) obtidos de células CHO-K1, incubadas por 1 e 24h com diferentes concentrações de própolis $(50-400 \mu \mathrm{g} / \mathrm{mL})$ e irradiadas com 5 Gy de ${ }^{60}$ Co.

\begin{tabular}{|c|c|c|c|}
\hline $\begin{array}{c}\text { Tempo de } \\
\text { incubação } \\
\text { com própolis }\end{array}$ & $\begin{array}{c}\text { Dose } \\
\text { (Gy) }\end{array}$ & $\begin{array}{c}\text { Concentração } \\
\text { de própolis } \\
(\mu \mathrm{g} / \mathrm{ml})\end{array}$ & $\begin{array}{l}\text { Viabilidade (\%) } \\
\text { (média } \pm \text { dp) }\end{array}$ \\
\hline 1 Hora & 0 & $\begin{array}{c}0 \\
50 \\
100 \\
200 \\
400 \\
0 \\
50 \\
100 \\
200 \\
400\end{array}$ & $\begin{array}{c}100,0 \pm 1,9 \\
99,2 \pm 2,1 \\
96,1 \pm 4,3 \\
104,6 \pm 3,5 \\
100,4 \pm 3,9 \\
95,6 \pm 3,6 \\
96,8 \pm 2,4 \\
96,7 \pm 7,1 \\
102,4 \pm 3,9 \\
90,1 \pm 5,4\end{array}$ \\
\hline 24 Horac & 0 & $\begin{array}{c}0 \\
50 \\
100 \\
200 \\
400\end{array}$ & $\begin{array}{c}100,0 \pm 15,1 \\
106,4 \pm 6,0 \\
102,4 \pm 8,4 \\
97,9 \pm 5,0 \\
91,2 \pm 8,4\end{array}$ \\
\hline & 5 & $\begin{array}{c}0 \\
50 \\
100 \\
200 \\
400\end{array}$ & $\begin{array}{l}90,0 \pm 7,0 \\
88,2 \pm 4,7 \\
87,7 \pm 8,0 \\
92,8 \pm 3,0 \\
77,5 \pm 5,6\end{array}$ \\
\hline
\end{tabular}


TABELA 4: Valores de viabilidade (\%) obtidos de células PC3, incubadas por 1 e 24h com diferentes concentrações de própolis $(50-400 \mu \mathrm{g} / \mathrm{mL})$ e irradiadas com 5 Gy de ${ }^{60}$ Co.

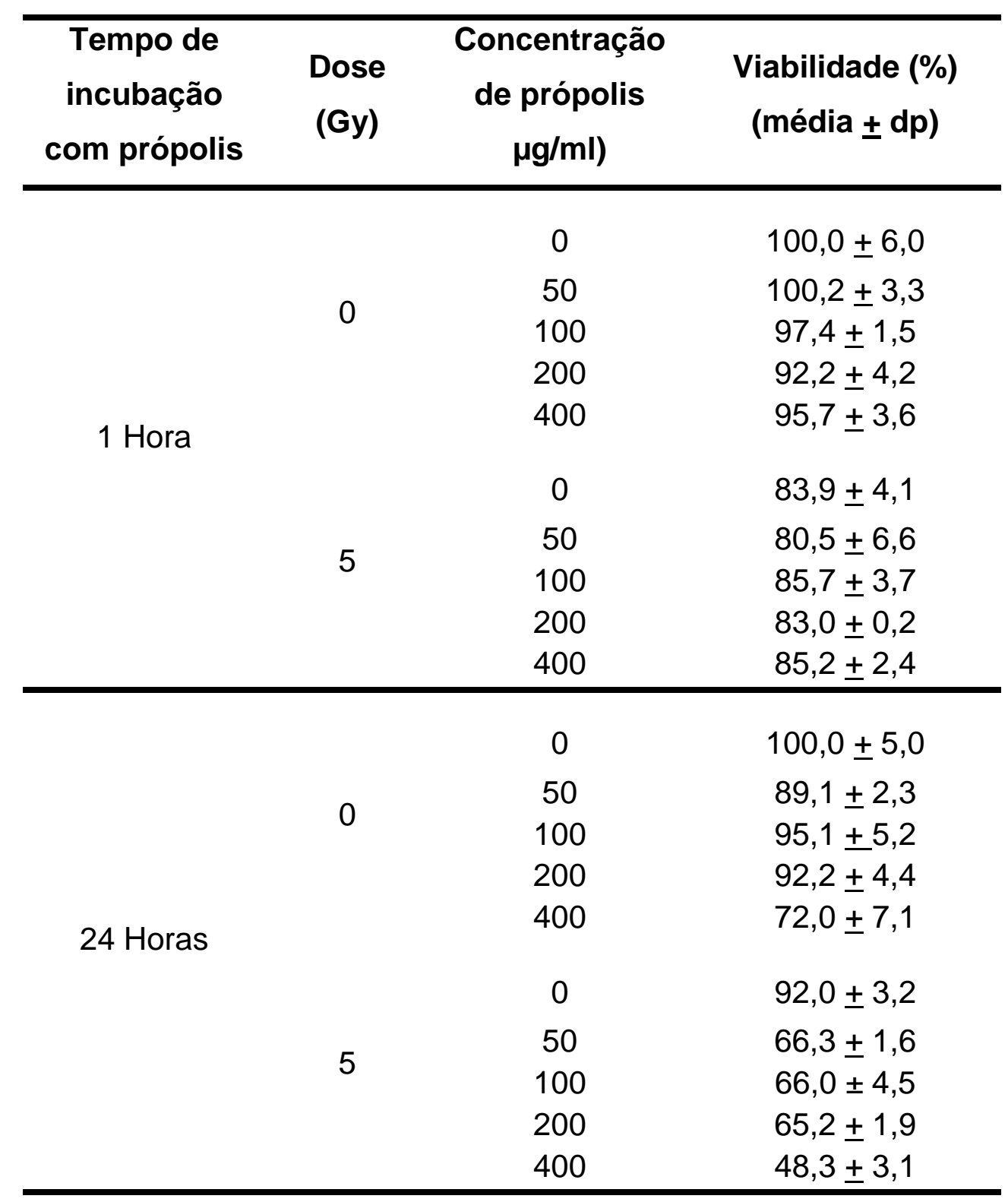

Uma representação gráfica da viabilidade celular em função dos diferentes tratamentos, consta nas Figuras 6 e 7, com 1 e 24h de pré-incubação, respectivamente. Levando-se em consideração o período de incubação de $1 \mathrm{~h}$, a própolis sozinha não foi citotóxica para células CHO-K1, com um pequeno aumento na viabilidade celular na concentração de $200 \mu \mathrm{g} / \mathrm{ml}$, porém sem significância estatística $(p>0,05)$ (Figura $6 \mathrm{~A}$ ). Já para as células $\mathrm{CHO}-\mathrm{K} 1$ irradiadas, a mesma concentração de própolis $(200 \mu \mathrm{g} / \mathrm{ml})$ causou um aumento na 
viabilidade que foi significativa $(p<0,05)$. Em células PC3, no entanto, uma concentração de $200 \mu \mathrm{g} / \mathrm{ml}$ induziu uma queda na viabilidade celular cuja diferença foi significativa $(p<0,05)$ o que, no entanto, não teve qualquer influencia em células PC3 irradiadas (Figura 6B).
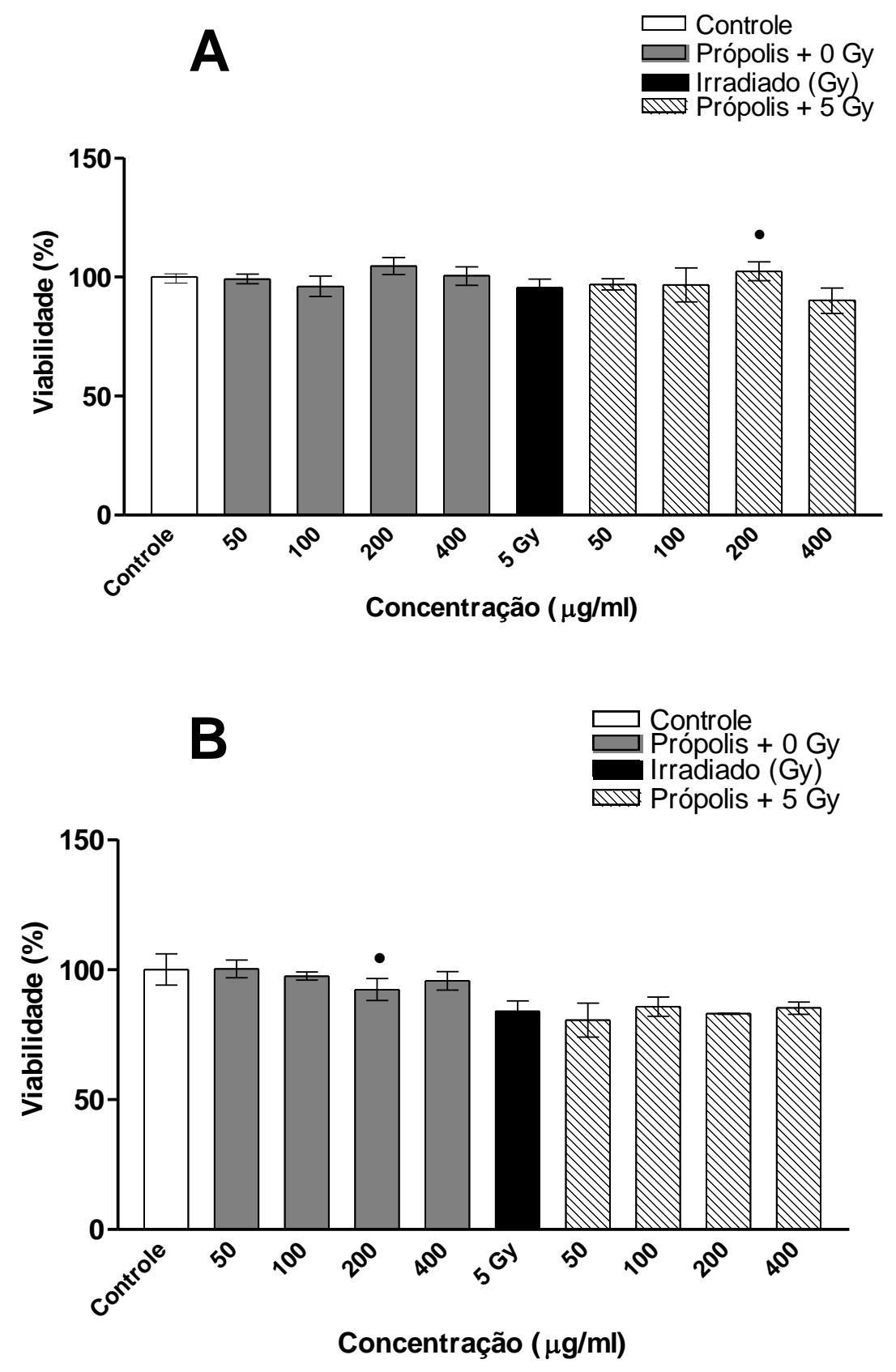

FIGURA 6: Efeito de diferentes concentrações de própolis $(50-400 \mu \mathrm{g} / \mathrm{mL})$ na viabilidade de células $\mathrm{CHO}-\mathrm{K} 1$ (A) e PC3 (B), incubadas por $1 \mathrm{~h}$ e irradiadas com 5 Gy de ${ }^{60} \mathrm{Co}$. - $p<0,05$. 
Para período de incubação de $24 \mathrm{~h}$ (Figura 7), a própolis nas concentrações de 50 e $100 \mu \mathrm{g} / \mathrm{ml}$ e também na de $200 \mu \mathrm{g} / \mathrm{ml}$ associadas com a radiação, estimulou aparentemente, a proliferação de células CHO-K1(Figura 7A), porém sem significância estatística $(p>0,05)$. Entretanto, a própolis na concentração mais alta de $400 \mu \mathrm{g} / \mathrm{ml}$, induziu uma queda significativa $(p<0,01)$ na viabilidade das células $\mathrm{CHO}$ irradiadas.

Em células PC3 (Figura 7B), o tratamento somente com a própolis produziu uma queda significativa na viabilidade nas concentrações de 50 ( $p$ < $0,05)$ e $400 \mu \mathrm{g} / \mathrm{ml}(p<0,001)$. O tratamento combinado com própolis + radiação induziu um decréscimo altamente significativo $(p<0,001)$ para todas as concentrações de própolis testadas $(50,100,200$ e $400 \mu \mathrm{g} / \mathrm{ml})$. 

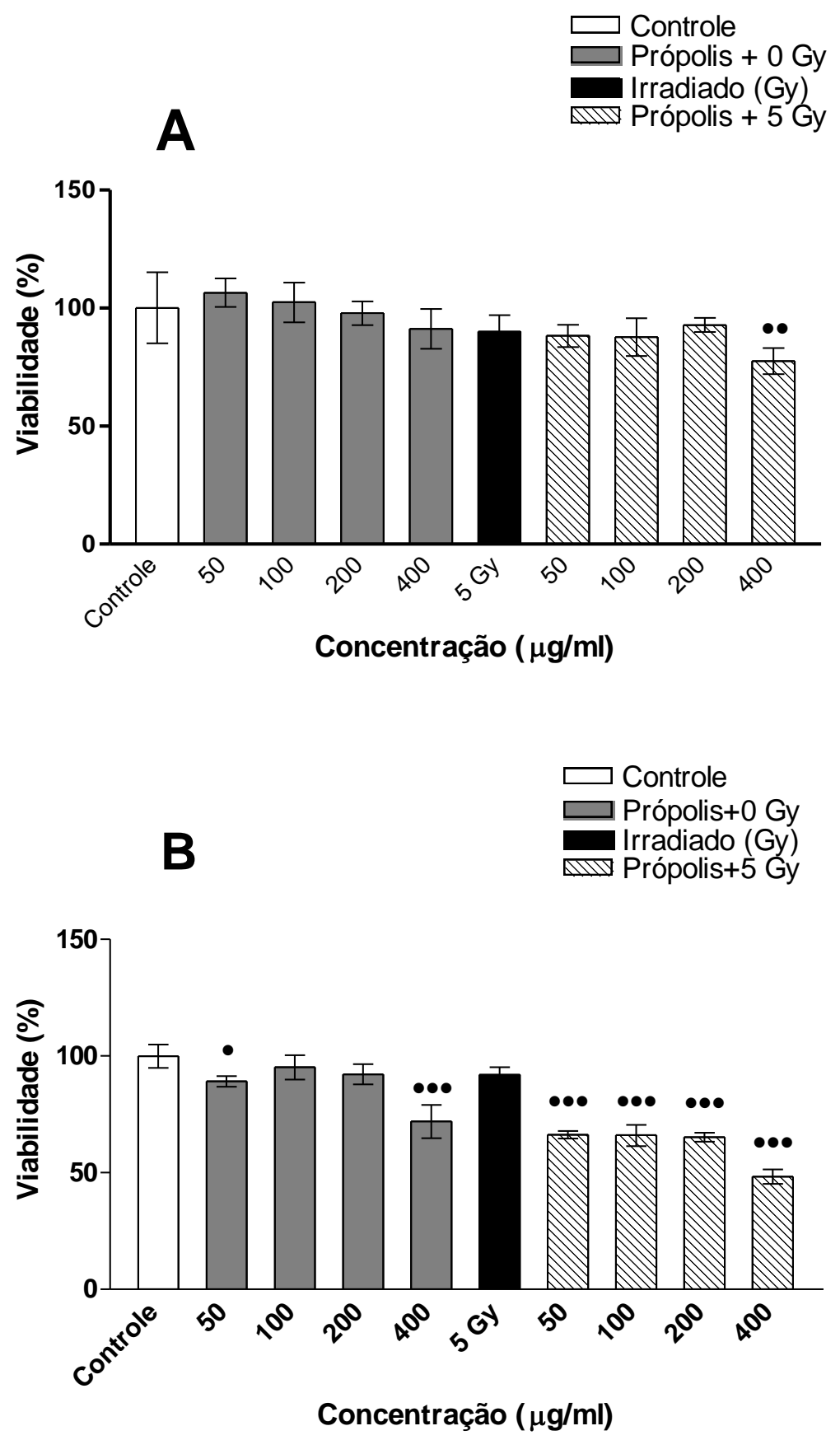

FIGURA 7: Efeito de diferentes concentrações de própolis $(50-400 \mu \mathrm{g} / \mathrm{mL})$ na viabilidade de células CHO-K1 (A) e PC3 (B), incubadas por $24 \mathrm{~h}$ e irradiadas com 5 Gy de ${ }^{60} \mathrm{Co}$. • $p<0,05, \bullet p<0,01, \bullet p<0,001$. 


\subsection{Formação de colônias}

Os dados obtidos sobre a clonogenicidade de células CHO-K1 e PC3, tratadas com diferentes concentrações de própolis e irradiadas estão apresentados nas Tabelas 5 e 6, respectivamente. As células $\mathrm{CHO}$ mostraram uma eficiência de plaqueamento relativamente alta (cerca de $92 \%$ ), ao passo que as células PC3, uma eficiência relativamente baixa, da ordem de $38 \%$.

TABELA 5: Fração de sobrevida e eficiência de plaqueamento de células $\mathrm{CHO}-\mathrm{K} 1$, tratadas com diferentes concentrações de própolis $(30-100 \mu \mathrm{g} / \mathrm{ml})$ e irradiadas com várias doses de radiação.

\begin{tabular}{|c|c|c|c|}
\hline Amostra & $\begin{array}{c}\text { Numero de } \\
\text { colônias contadas } \\
\text { (média } \pm \text { SEM) }\end{array}$ & $\begin{array}{c}\text { Eficiência de } \\
\text { plaqueamento (\%) } \\
\text { (média } \pm \text { SEM) }\end{array}$ & $\begin{array}{c}\text { Fração de } \\
\text { sobrevida } \\
\text { (média_SEM) }\end{array}$ \\
\hline $0 \mu \mathrm{g} / \mathrm{ml}$ & $277,7 \pm 10,3$ & $92,6 \pm 3,4$ & $1,00 \pm 0,00$ \\
\hline $30 \mu \mathrm{g} / \mathrm{ml}$ & $228,0 \pm 2,1$ & & $0,82 \pm 0,01$ \\
\hline $50 \mu \mathrm{g} / \mathrm{ml}$ & $300,0 \pm 17,6$ & & $1,08 \pm 0,06$ \\
\hline $100 \mu \mathrm{g} / \mathrm{ml}$ & $184,0 \pm 14,5$ & & $0,66 \pm 0,05$ \\
\hline $1 \mathrm{~Gy}$ & $183,7 \pm 5,8$ & & $0,66 \pm 0,02$ \\
\hline $30 \mu \mathrm{g} / \mathrm{ml}+1 \mathrm{~Gy}$ & $160,0 \pm 7,1$ & & $0,58 \pm 0,03$ \\
\hline $50 \mu \mathrm{g} / \mathrm{ml}+1 \mathrm{~Gy}$ & $276,0 \pm 3,8$ & & $0,99 \pm 0,01$ \\
\hline $100 \mu \mathrm{g} / \mathrm{ml}+1 \mathrm{~Gy}$ & $215,7 \pm 9,7$ & & $0,78 \pm 0,03$ \\
\hline 2Gy & $155,0 \pm 5,1$ & & $0,56 \pm 0,02$ \\
\hline $30 \mu \mathrm{g} / \mathrm{ml}+2 \mathrm{~Gy}$ & $138,0 \pm 9,2$ & & $0,50 \pm 0,03$ \\
\hline $50 \mu \mathrm{g} / \mathrm{ml}+2 \mathrm{~Gy}$ & $298,7 \pm 9,7$ & & $1,07 \pm 0,04$ \\
\hline $100 \mu \mathrm{g} / \mathrm{ml}+2 \mathrm{~Gy}$ & $178,7 \pm 5,8$ & & $0,64 \pm 0,02$ \\
\hline 4Gy & $73,0 \pm 3,2$ & & $0,27 \pm 0,01$ \\
\hline $30 \mu \mathrm{g} / \mathrm{ml}+4 \mathrm{~Gy}$ & $124,7 \pm 4,8$ & & $0,45 \pm 0,02$ \\
\hline $50 \mu \mathrm{g} / \mathrm{ml}+4 \mathrm{~Gy}$ & $119,7 \pm 3,9$ & & $0,43 \pm 0,01$ \\
\hline $100 \mu \mathrm{g} / \mathrm{ml}+4 \mathrm{~Gy}$ & $163,0 \pm 7,2$ & & $0,59 \pm 0,03$ \\
\hline 6Gy & $33,0 \pm 5,7$ & & $0,12 \pm 0,02$ \\
\hline $30 \mu \mathrm{g} / \mathrm{ml}+6 \mathrm{~Gy}$ & $63,0 \pm 2,9$ & & $0,23 \pm 0,01$ \\
\hline $50 \mu \mathrm{g} / \mathrm{ml}+6 \mathrm{~Gy}$ & $39,3 \pm 0,9$ & & $0,14 \pm 0,00$ \\
\hline $100 \mu \mathrm{g} / \mathrm{ml}+6 \mathrm{~Gy}$ & $26,0 \pm 2,3$ & & $0,09 \pm 0,01$ \\
\hline
\end{tabular}


TABELA 6: Fração de sobrevida e eficiência de plaqueamento de células PC3, tratadas com diferentes concentrações de própolis $(30-100 \mu \mathrm{g} / \mathrm{mL})$ e irradiadas com várias doses de radiação.

\begin{tabular}{|c|c|c|c|}
\hline Amostra & $\begin{array}{c}\text { Numero de colônias } \\
\text { contadas } \\
\text { (média } \pm \text { SEM) }\end{array}$ & $\begin{array}{c}\text { Eficiência de } \\
\text { plaqueamento (\%) } \\
\text { (média } \pm \text { SEM) }\end{array}$ & $\begin{array}{c}\text { Fração de } \\
\text { sobrevida } \\
\text { (média_SEM) }\end{array}$ \\
\hline $0 \mu \mathrm{g} / \mathrm{ml}$ & $76,3 \pm 3,8$ & $38,1 \pm 1,9$ & $1,00 \pm 0,00$ \\
\hline $\begin{array}{c}30 \mu \mathrm{g} / \mathrm{ml} \\
50 \mu \mathrm{g} / \mathrm{ml} \\
100 \mu \mathrm{g} / \mathrm{ml}\end{array}$ & $\begin{array}{l}86,0 \pm 3,5 \\
91,0 \pm 1,5 \\
90,0 \pm 8,0\end{array}$ & & $\begin{array}{l}1,13 \pm 0,05 \\
1,19 \pm 0,02 \\
1,18 \pm 0,11\end{array}$ \\
\hline $\begin{array}{c}1 \mathrm{~Gy} \\
30 \mu \mathrm{g} / \mathrm{ml}+1 \mathrm{~Gy} \\
50 \mu \mathrm{g} / \mathrm{ml}+1 \mathrm{~Gy} \\
100 \mu \mathrm{g} / \mathrm{ml}+1 \mathrm{~Gy}\end{array}$ & $\begin{array}{c}57,7 \pm 1,5 \\
45,7 \pm 11,3 \\
54,0 \pm 1,2 \\
61,7 \pm 4,3\end{array}$ & & $\begin{array}{l}0,76 \pm 0,02 \\
0,60 \pm 0,15 \\
0,71 \pm 0,01 \\
0,81 \pm 0,06\end{array}$ \\
\hline $\begin{array}{c}2 \mathrm{~Gy} \\
30 \mu \mathrm{g} / \mathrm{ml}+2 \mathrm{~Gy} \\
50 \mu \mathrm{g} / \mathrm{ml}+2 \mathrm{~Gy} \\
100 \mu \mathrm{g} / \mathrm{ml}+2 \mathrm{~Gy}\end{array}$ & $\begin{array}{l}41,0 \pm 3,6 \\
37,0 \pm 1,2 \\
50,7 \pm 1,2 \\
47,3 \pm 7,7\end{array}$ & & $\begin{array}{l}0,54 \pm 0,05 \\
0,48 \pm 0,02 \\
0,66 \pm 0,02 \\
0,62 \pm 0,10\end{array}$ \\
\hline $\begin{array}{c}\text { 4Gy } \\
30 \mu \mathrm{g} / \mathrm{ml}+4 \mathrm{~Gy} \\
50 \mu \mathrm{g} / \mathrm{ml}+4 \mathrm{~Gy} \\
100 \mu \mathrm{g} / \mathrm{ml}+4 \mathrm{~Gy}\end{array}$ & $\begin{array}{l}9,3 \pm 0,7 \\
4,7 \pm 1,9 \\
7,7 \pm 2,2 \\
7,3 \pm 2,8\end{array}$ & & $\begin{array}{l}0,12 \pm 0,01 \\
0,06 \pm 0,02 \\
0,10 \pm 0,03 \\
0,09 \pm 0,04\end{array}$ \\
\hline $\begin{array}{c}\text { 6Gy } \\
30 \mu \mathrm{g} / \mathrm{ml}+6 \mathrm{~Gy} \\
50 \mu \mathrm{g} / \mathrm{ml}+6 \mathrm{~Gy} \\
100 \mu \mathrm{g} / \mathrm{ml}+6 \mathrm{~Gy}\end{array}$ & $\begin{array}{l}0,0 \pm 0,0 \\
0,0 \pm 0,0 \\
0,0 \pm 0,0 \\
0,0 \pm 0,0\end{array}$ & & $\begin{array}{l}0,00 \pm 0,00 \\
0,00 \pm 0,00 \\
0,00 \pm 0,00 \\
0,00 \pm 0,00\end{array}$ \\
\hline
\end{tabular}

A Figura 8 mostra as curvas de sobrevida de células CHO-K1 (Figura 8A) e PC3 (Figura 8 B), obtidas mediante teste de formação de colônias, ajustadas pelo modelo exponencial. 


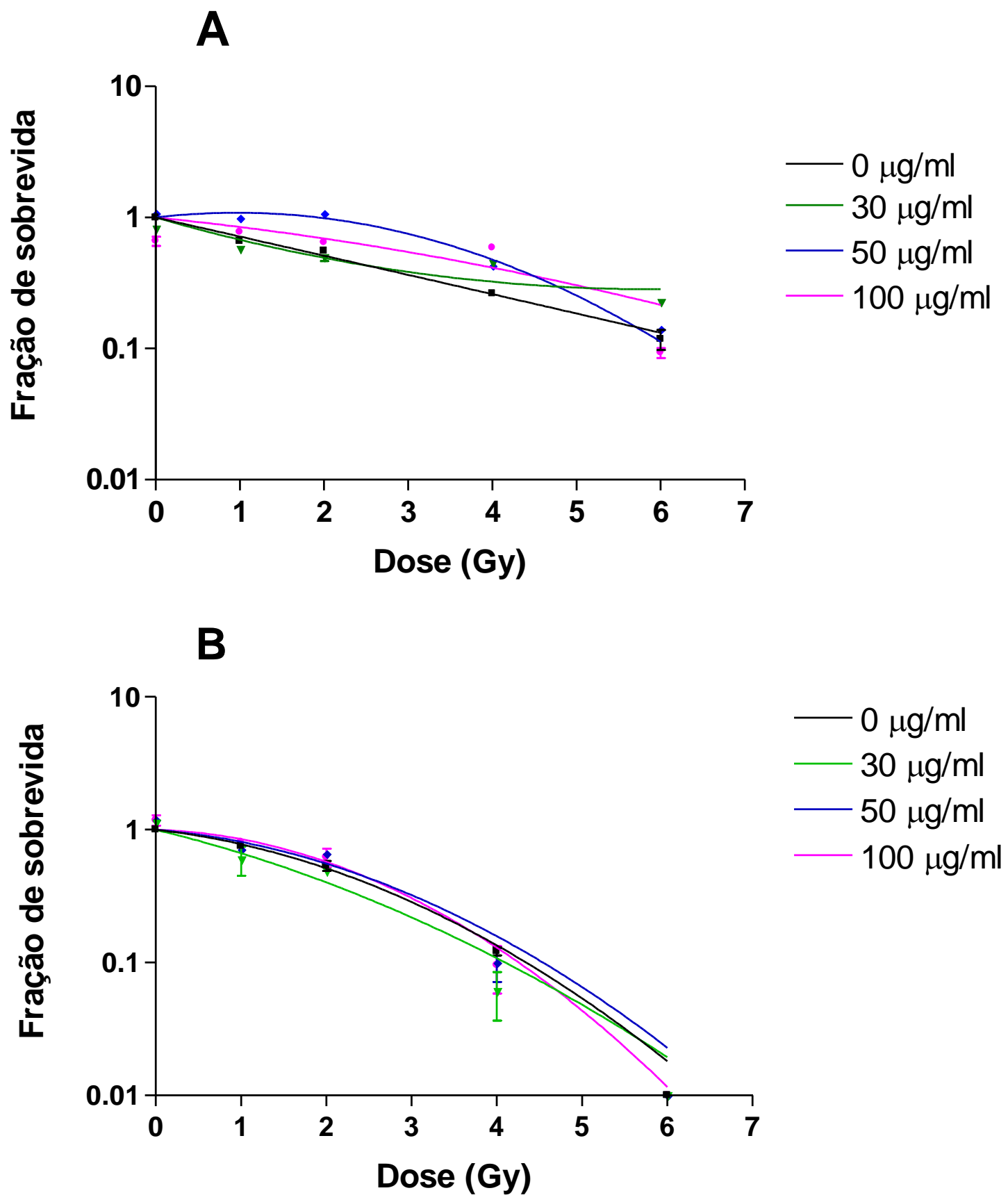

FIGURA 8: Curvas de sobrevidas ajustadas pelo modelo linear quadrático $\left(Y=e^{-\alpha D-\beta D 2}\right)$ obtidas de células CHO-K1 (A) e PC3 (B), tratadas com diferentes concentrações de própolis (30-100 $\mu \mathrm{g} / \mathrm{mL})$ em função da dose de radiação.

Em células $\mathrm{PC}$, o pré-tratamento com diferentes concentrações de própolis $(30,50$ e $100 \mu \mathrm{g} / \mathrm{ml})$ resultou em curvas de sobrevida similares entre si, ao passo que em células $\mathrm{CHO}$, o pré-tratamento com própolis na concentração de $50 \mu \mathrm{g} / \mathrm{ml} \mathrm{e}$, em menor intensidade, na de $100 \mu \mathrm{g} / \mathrm{ml}$, teve um efeito estimulador na capacidade reprodutiva das células, quando comparadas com a curva de sobrevida controle, somente com a radiação. 
Os valores dos coeficientes do modelo linear-quadrático bem como os valores do $r^{2}$ para cada uma das curvas dose-resposta estão expressos na Tabela 7.

Os dados obtidos ajustaram satisfatoriamente ao modelo matemático. Houve um predomínio do componente linear (coeficiente $\alpha$ ) nas duas linhagens celulares, exceto para curva de $100 \mu \mathrm{g} / \mathrm{ml}$ em células PC3. As células $\mathrm{CHO}$ apresentaram valores do coeficiente linear mais altos que os das células PC3.

TABELA 7: Valores dos coeficientes $\alpha$ e $\beta$ do modelo linear - quadrático $\left(Y=e^{-\alpha D-\beta D 2}\right)$ para células $\mathrm{CHO}-\mathrm{K} 1$ e $\mathrm{PC} 3$, tratadas com várias concentrações de própolis $(30-100 \mu \mathrm{g} / \mathrm{mL})$ e irradiadas com 1-6 Gy de ${ }^{60} \mathrm{Co}$.

\begin{tabular}{ccccc}
\hline $\begin{array}{c}\text { Linhagem } \\
\text { Celular }\end{array}$ & $\begin{array}{c}\text { Amostra de } \\
\text { própolis } \\
(\boldsymbol{\mu} \mathbf{g} / \mathrm{ml})\end{array}$ & $\boldsymbol{\alpha}( \pm$ SEM $) \times 10^{-2}$ & $\boldsymbol{\beta}( \pm$ SEM $) \times 10^{-2}$ & $\mathbf{r}^{2}$ \\
\hline & 0 & $33,480 \pm 3,439$ & $0,047 \pm 0,931$ & 0,9778 \\
& 30 & $42,730 \pm 7,860$ & $3,620 \pm 1,654$ & 0,6523 \\
CHO & 50 & $17,290 \pm 4,170$ & $8,949 \pm 1,321$ & 0,9514 \\
& 100 & $14,880 \pm 10,470$ & $1,788 \pm 2,622$ & 0,3956 \\
& & & & \\
& 0 & $16,610 \pm 4,849$ & $8,372 \pm 2,159$ & 0,9833 \\
& 30 & $35,530 \pm 14,890$ & $5,030 \pm 6,633$ & 0,9083 \\
PC3 & 50 & $12,500 \pm 10,430$ & $8,409 \pm 4,456$ & 0,9311 \\
& 100 & $4,531 \pm 12,900$ & $11,630 \pm 6,065$ & 0,9124 \\
& & & & \\
\hline
\end{tabular}

Embora, a sobrevida de células $\mathrm{CHO}(\mathrm{FS}=0,56 \pm 0,02)$ seja similar à de PC3 (FS $=0,54 \pm 0,05$ ) após a exposição com 2 Gy de ${ }^{60} \mathrm{Co}$, elas mostraram uma maior radiorresistência nas doses mais altas de $4(0,27 \pm 0,01)$ e 6 Gy $(0,12$ $\pm 0,02)$ em relação às células PC3 irradiadas $(0,12 \pm 0,01$ e $0,0 \pm 0,0)$. 


\section{DISCUSSÃO}

O presente estudo foi proposto para averiguar a influência da própolis brasileira, particularmente própolis procedente de Rio Grande do Sul (AF-08) sobre danos genotóxico, citotóxico e também no potencial proliferativo de células normais (CHO-K1) e tumorais (PC3), irradiadas com ${ }^{60} \mathrm{Co}$. Os $\mathrm{MN}$ representam danos no DNA não reparados e estão envolvidos nos processos de grande significado biológico como malformação, envelhecimento e indução de câncer. Diferentes modalidades de morte celular interfásica (apoptose e necrose) e morte clonogênica representam diferentes manifestações celulares em resposta à ação dos agentes agressores.

O ensaio do MN permitiu observar que a própolis nas concentrações testadas mostrou um efeito protetor, diminuindo a quantidade de danos radioinduzidos no DNA de células $\mathrm{CHO}$ e $\mathrm{PC} 3$, em relação aos respectivos controle, nos 2 parâmetros analisados (Figuras. 4 e 5 ). $O$ efeito radioprotetor foi mais pronunciado na concentração mais baixa de própolis, observado pela redução na freqüência de $\mathrm{MN}$. Para células $\mathrm{CHO}$, a concentração de própolis que mostrou uma melhor eficiência na redução do dano foi a de $30 \mu \mathrm{g} / \mathrm{ml}$ quando irradiadas com 1 Gy (redução máxima de dano de $60 \%$ ) (Figura 4). Para células PC3 ocorreu na faixa de $5-15 \mu \mathrm{g} / \mathrm{ml}$, com redução de dano da ordem de $40-57$ $\%$. A própolis foi efetiva em minimizar o efeito da radiação mesmo na concentração de $5 \mu \mathrm{g} / \mathrm{ml}$, a mais baixa usada. Um maior aumento na concentração de própolis (50 e 100 $\mu \mathrm{g} / \mathrm{ml}$ ) não resultou no aumento proporcional na redução da genotoxicidade, embora mostrasse um efeito radioprotetor, mesmo na dose mais alta de 4 Gy, porém sem significância estatística $(p>0,05)$

Resultados similares foram obtidos por outros autores (Jagetia, 2003; Rithidech et al., 2005). Rithidech et al (2005) verificaram que a apigenina, um dos componentes da própolis, exibiu um efeito radioprotetor na indução de $M N$, somente na concentração de $10 \mu \mathrm{g} / \mathrm{ml}$ ( 32\% de redução na frequência de MN) 
em linfócitos humanos tratados com diferentes concentrações de apigenina (2,5 $25 \mu \mathrm{g} / \mathrm{ml}), 30$ minutos antes da irradiação com 2 Gy de ${ }^{137}$ Cs. Os autores verificaram que, aumentando a concentração de própolis acima da ótima não conferiu efeito esperado na indução de MN. Prasad et al. (2002) observaram que extrato etanólico de Coleus aromaticus, uma planta medicinal popularmente usada na Índia, foi mais efetivo conferindo efeito anticlastogênico nas concentrações mais baixas e acima desta concentração, resultou somente em um efeito aditivo. Nossos resultados são concordantes com os previamente reportados (Rithidech et al., 2005), em que cada radioprotetor deva ter uma concentração ótima para a sua ação.

Cabe salientar que a própolis sozinha não foi genotóxica para células $\mathrm{CHO}$ e PC3, mesmo na concentração mais alta de $100 \mu \mathrm{g} / \mathrm{ml}$, não exibindo quaisquer danos adicionais ao DNA. As células PC3 mostraram danos basais espontâneos mais altos que a CHO. Uma possível explicação pode ser em decorrência do seu próprio "status" de malignidade ou devido a uma instabilidade genética intrínseca adquirida, característica dessas células.

Embora o mecanismo exato da ação da própolis na radioproteção não está totalmente elucidado, vários estudos têm mostrado que as propriedades farmacológicas da própolis são atribuíveis, principalmente, à presença de flavonóides pela sua ação como "scavengers" de radicais livres (Rithidech et al., 2005). Tais "scavengers" de radicais livres provavelmente têm um papel chave em radioproteção porque a radiação induz toxicidade que é mediada principalmente através da geração de radicais livres e sua ação no DNA (Montoro et al., 2011).

Os dados obtidos pelo teste de citotoxicidade mostraram também que a própolis sozinha não foi capaz de danificar células $\mathrm{CHO}$, mesmo na concentração mais alta utilizada $(400 \mu \mathrm{g} / \mathrm{ml})$ (Figuras 6 e 7). Todavia, para células PC3, o extrato etanólico exibiu um efeito antiproliferativo (50, 200 e $400 \mu \mathrm{g} / \mathrm{ml})$ significativo. Contrariamente, em células $\mathrm{CHO}-\mathrm{K} 1$, o tratamento combinado com a própolis $(200 \mu \mathrm{g} / \mathrm{ml})$ e radiação, estimulou o crescimento celular e só foi citotóxica na concentração mais alta de $400 \mu \mathrm{g} / \mathrm{ml}$ associada à radiação quando incubadas por 24h. Cumpre salientar que, para células tumorais PC3, o extrato etanólico de própolis inibiu o crescimento das células, em todas as concentrações testadas, 
potencializando o efeito da radiação, cuja queda na viabilidade celular foi altamente significativa $(\mathrm{p}<0,001)$.

De posse nessas observações, pode-se dizer que a própolis mostrou um efeito estimulador de proliferação para células $\mathrm{CHO}$ e um efeito antiproliferativo para células tumorais de próstata PC3, aumentando a taxa de morte celular. Essa ação antiproliferativa da própolis tem sido observada em outras linhagens tumorais, tais como, carcinoma do colon humano ( $\mathrm{CaCo} 2$, HCT116, HT29, SW480), carcinoma de colon murino (26-L5), melanoma de murino (B16-BL6), fibrosarcoma humano (HT1080), adenocarcinoma humano de pulmão (A549) e carcinoma de próstata (DU145) (Russo et al., 2004; Ishihara et al., 2009; Li et al., 2009). Assim sendo, as nossas observações juntamente com os dados descritos por outros autores, mostram um amplo espectro de propriedades antiproliferativas de extratos de própolis para várias linhagens celulares de carcinoma. No entanto, os mecanismos exatos da sua atividade anticarcinogênica permanecem pouco compreendidos.

Há constatação de que essa atividade inibidora da própolis no crescimento de células tumorais, está intimamente associada com a indução de apoptose (Chen et al., 2007), demonstrada tanto pela análise de eletroforese de gel (Palayoor et al., 1998; Akao et al., 2003) como pela citometria de fluxo (fração sub-G1) (Ishihara et al., 2009).

Ishihara et al. (2009) verificaram que a expressão dos genes p21 e p53 são responsáveis, pelo menos em parte, na indução de apoptose e consequentemente, na inibição do crescimento de várias linhagens celulares do carcinoma de cólon humano, mediada pelo extrato de própolis. O p53 é um gene supressor tumoral que representa um papel crítico na indução de apoptose em resposta ao dano induzido no DNA, bem como no controle da progressão do ciclo celular e na manutenção da integridade do genoma. Os autores observaram ainda que tanto as linhagens celulares com p53 selvagem (HCT116) como àquelas mutantes de p53 (HT29 e SW480) foram igualmente sensíveis à inibição do crescimento induzida pelo extrato de própolis. Estes resultados permitiram aos autores a sugerir o envolvimento de rotas dependente e independente de p53 para a indução de apoptose, também em células com p53 mutante, o que pode 
incluir também células PC3 do presente estudo. Entretanto, futuras investigações são necessárias. As duas linhagens celulares utilizadas no presente estudo são mutantes de p53 e, portanto, não expressam proteína p53. As células CHO-K1 apresentam uma mutação no códon 211 (exon 6) do gene p53 com alteração de Thr (ACA) para Lys (AAA) na região do "binding" do DNA ( Hsu et al., 1999) e morrem predominantemente pela necrose. A morte por apoptose representa somente < 1,5\% em células $\mathrm{CHO}$ irradiadas (Murakami et al., 2004). Por outro lado, as células PC3 são hemizigotas para o cromossomo 17 e a sua única cópia do gene p53 tem uma deleção no códon 138 que causa uma mutação do tipo "frameshift" e uma nova composição pára o códon na posição 169. Consequentemente, células PC3 não expressam proteína p53 (p53 null) (Scott et al., 2003).

Além da indução de apoptose, uma outra possibilidade aventada para tentar explicar a ação antiproliferativa da própolis, é o possível envolvimento da própolis/componentes, na regulação do ciclo celular, através da estimulação da expressão de certos genes (por exemplo, p21, p53, ciclina, CDK) Resultados obtidos de estudos in vitro mostraram que a apigenina na concentração de $>20$ $\mu \mathrm{M}$, efetivamente modula reguladores do ciclo celular, induzindo um bloqueio na fronteira G2/M em keratinócitos de camundongos (C50) e em células leucêmicas humanas (HL-60) (Lepley et al., 1996). Subsequentemente, foi demonstrado que concentração mais baixa de apigenina (10 $\mu \mathrm{M})$ induziu um bloqueio no G2/M em células de câncer de próstata humana, mas não em linhagem normal de células epiteliais de próstata (McVean et al., 2002). McVean et al. (2002) relataram que a inibição de crescimento induzida pela apigenina em keratinócitos de camundongos, provavelmente não ocorre como consequência de mecanismos citotóxicos ou pela indução de apoptose, mas pode ser resultante da modulação de proteínas reguladoras do ciclo celular, um efeito que não tem sido estudado extensivamente. Possivelmente, o tratamento com apigenina, ativa proteína p53, resultando na indução da proteína p21, levando a um bloqueio no G2/M. O p21 é de interesse particular, desde que este gene representa um papel crítico no desenvolvimento de carcinomas humanos, regulando negativamente a atividade do complexo ciclina D1/kinase dependente de ciclina (CDK) via mecanismo dependente ou independente de p53 (Ishihara et al., 2009). Análise da expressão 
de proteínas pelo "Western blot" para investigar genes envolvidos na regulação do ciclo celular, mostrou uma alta expressão do p21, mas não as de ciclinas D1, B1 e kinase dependente de ciclina (CDK4) (Li et al., 2007) em células PC3. Da mesma maneira, Li et al. (2007) verificaram um bloqueio na fase G2 do ciclo celular quando células PC3 e também DU145, ambas tumorais de próstata, foram submetidas à ação da própolis. Estes dados sugerem atividade antiproliferativa da própolis brasileira em células tumorais de próstata, associada com o bloqueio do ciclo celular.

Kastan et al. (1991) verificaram que tanto células que expressam p53 selvagem (ML-1) como àquelas que não expressam (HL-60) ou que expressam uma forma mutante de p53 (células RPMI 8402) exibiram um bloqueio no G2 após a irradiação com gama, o que mostra que o bloqueio no G2 independe do "status" do p53. No entanto, células hematopoiéticas, leucêmicas (ML-1) ou não (células progenitoras normais da medula) que expressam p53 selvagem apresentaram também um bloqueio na fase G1 do ciclo celular após o dano no DNA. Estas observações indicam um papel da proteína p53 selvagem participando no controle do ciclo celular, inibindo a síntese do DNA após o dano no DNA, via bloqueio no G1, mas provavelmente, não contribui significativamente no bloqueio no G2. Os autores sugeriram um novo mecanismo para o qual, a perda do p53 selvagem pode contribuir para a tumorigênese (rota independente de p53).

A morte reprodutiva foi também avaliada no presente estudo como uma outra modalidade de morte celular, pelo teste clássico de formação de colônias, na obtenção de curva de sobrevida. A perda da habilidade em formar colônias é um evento crítico em radioterapia do tumor. O problema clínico de recorrência do tumor envolve algumas células que não somente sobrevivem durante 0 tratamento radioterápico, mas retém a habilidade de proliferar e repopular o tumor, propagando a malignidade (Scott et al., 2003).

As curvas de sobrevida obtidas para ambas as linhagens celulares foram melhor ajustadas pelo modelo exponencial quadrático. A eficiência de plaqueamento (EP) das células PC3 foi cerca de 2,4 vezes mais baixa $(38,1 \pm 1,9$ $\%)$ que a de células CHO-K1 (92,6 $\pm 3,4 \%)$. Valores diferentes de EP foram reportados na literatura: 0,55 \pm 0,05 (Palayoor et al., 1997), 0,30 $\pm 0,01$ (Scott et 
al., 2004) e 0,70 \pm 0,01 (Palayoor et al., 1998), provavelmente decorrentes de diferentes condições experimentais empregadas.

Cabe mencionar a ocorrência de células destacadas do substrato em cultura de monocamada, cuja freqüência foi mais acentuada em células PC3 em relação as células $\mathrm{CHO}-\mathrm{K} 1$ (dados não mostrados). Igualmente, Palayoor et al. (1998) verificaram um aumento na proporção de células PC3 irradiadas, desprendidas do substrato que eram "trypan-blue" positivas, com freqüência aumentada pelo tratamento combinado com ibuprofen, um anti-inflamatório usado para o alívio dos efeitos colaterais da radioterapia. Análise do DNA pela eletroforese de gel de agarose mostrou uma fragmentação internucleossômica do DNA, característica de apoptose, enquanto que células aderidas ao substrato não exibiram tal fragmentação do DNA.

Diante dessas observações, pode-se hipotetizar que, um conjunto de células micronucleadas danificadas, células apoptóticas e necróticas e também áquelas bloqueadas numa determinada fase do ciclo celular, pode representar uma fração significativa da população de células PC3 e que são provavelmente responsáveis pela porção exponencial da curva de sobrevida nas doses mais altas.

Tendo em vista que as curvas de sobrevida de células PC3 mostraram perfis similares sob diferentes tratamentos, permite hipotetizar que o extrato de própolis não influenciou no potencial clonogênico das células. Para células $\mathrm{CHO}$ $\mathrm{K} 1$, no entanto, o tratamento combinado com própolis (50 e $100 \mu \mathrm{g} / \mathrm{ml}$ ) e radiação, mostrou um efeito estimulador da proliferação celular, nas doses de 2 e 4 Gy, clinicamente relevantes.

Embora a própolis utilizada no presente estudo é conhecida por não apresentar artepilina C na sua composição química, foi capaz de mostrar um efeito radioprotetor, tanto citotóxica como genotoxicamente. Como os componentes da própolis ainda não tem sido totalmente identificados ou caracterizados, torna-se difícil atribuir o efeito observado a qualquer um dos componentes. Além disso, existe a possibilidade da própolis conter outros princípios ativos ainda não identificados. Ainda, o grau de proteção pode 
depender dos efeitos destes agentes isolada ou conjuntamente contra o dano celular induzido pela radiação. Dessa forma, estudos visando a identificação de origem vegetal da própolis, caracterização de compostos biologicamente ativos (Daugsch et al., 2007) e a sua atividade biológica, têm recebido uma atenção especial nestes últimos anos no mundo inteiro.

A despeito do amplo espectro de atividade da própolis e da sua reconhecida eficácia em vários sistemas biológicos, o mecanismo exato da sua ação na proteção contra o dano da radiação é pouco conhecido. Além da sua possível atividade antioxidante mediada principalmente pelos flavonóides, que exercem sua ação pela captura de radicais livres, responsáveis pelo estresse oxidativo (Chen et al., 2004), várias hipóteses foram aventadas. Jeon et al. (2002) mostraram que os flavonóides de própolis estimulam a síntese do RNAm de enzimas antioxidantes endógena (catalase, superóxido dismutase e glutationa peroxidase). Sugere-se que a elevação dos níveis destas enzimas pelos flavonóides pode ser responsável pela proteção contra dano radioinduzido, reduzindo a quantidade de radicais livres e espécies reativas de $\mathrm{O}_{2}$ e consequentemente, aumentando a produção de moléculas capazes de proteção contra o estresse oxidativo.

Há relatos também de que a própolis e seus compostos polifenólicos estimulam a síntese de enzimas de reparo do DNA como glicosilase, endonuclease e polimerase $\beta$ do DNA (Benkovic et al., 2008).

Em modelo animal, vários autores aventaram uma possível atividade imunomoduladora dos flavonóides, estimulando células imunocompetentes (macrófagos, células T citotóxicas, células B e "Natural Killers") que representam um papel central na resistência às infecções secundárias associadas com a irradiação, contribuindo na posterior recuperação hematopoética e no aumento da sobrevida após a linfo e mielosupressão em animais irradiados (Orsolic et al., 2005).

Embora os constituintes da própolis responsáveis pela sua ação anti citotóxica/genotóxica não foram investigados no presente estudo, este tipo de abordagem pode proporcionar novas perspectivas para investigações posteriores, 
no sentido de vislumbrar um potencial uso da própolis na prevenção ou proteção contra à ação dos genotóxicos ambientais, incluindo a radiação ionizante. 


\section{CONCLUSÃO}

Os dados obtidos sobre influência da própolis (AF-08) na indução de danos induzidos pela radiação $\gamma$ de ${ }^{60} \mathrm{Co}$ em células $\mathrm{CHO}-\mathrm{K} 1$ e PC3, nas condições experimentais empregadas, permitiram concluir que:

- O extrato etanólico de própolis per se não apresentou qualquer efeito genotóxico, pelo menos nas concentrações testadas $(5-100 \mu \mathrm{g} / \mathrm{ml})$, tanto para células $\mathrm{CHO}$ como para $\mathrm{PC} 3$;

- Células submetidas ao tratamento combinado com própolis + radiação mostraram freqüência de $\mathrm{MN}$ menor que àquelas somente irradiadas, tanto para células $\mathrm{CHO}-\mathrm{K} 1$ como para $\mathrm{PC} 3$, mostrando um efeito radioprotetor na indução de dano genotóxico;

- O efeito radioprotetor foi mais pronunciado nas concentrações mais baixas de própolis $(5-30 \mu \mathrm{g} / \mathrm{ml})$ e nas doses mais baixas (1 Gy), nas duas linhagens celulares;

- As células PC3 exibiram dano espontâneo e também dano radioinduzido mais altos que as células $\mathrm{CHO}-\mathrm{K} 1$, indicando uma maior suscetibilidade na indução de $\mathrm{MN}$;

- A própolis per se não foi citotóxica para células CHO-K1 nas concentrações testadas $(50-400 \mu \mathrm{g} / \mathrm{ml})$, ao passo que para células PC3, mostrou um efeito antiproliferativo significativo nas concentrações de 50 , 200 e $400 \mu \mathrm{g} / \mathrm{ml}$;

- O tratamento combinado com própolis + radiação, mostrou um efeito antiproliferativo em todas as concentrações de própolis analisadas (50 $400 \mu \mathrm{g} / \mathrm{ml}$ ) em células PC3, potencializando o efeito da radiação, afetando a viabilidade celular; 
- Em células irradiadas, o tratamento com a própolis na concentração de 400 $\mu \mathrm{g} / \mathrm{ml}$ teve um efeito tóxico para células $\mathrm{CHO}-\mathrm{K} 1$ e altamente tóxico para células PC3 quando incubadas por 24h antes da irradiação;

- A eficiência de plaqueamento das células PC3 (38,1 $\pm 1,9 \%)$ foi cerca de 2,4 vezes mais baixa que a das células $\mathrm{CHO}-\mathrm{K} 1(92,6 \pm 3,4 \%)$;

- As curvas de sobrevida das duas linhagens celulares tratadas com diferentes concentrações de própolis (30,50 e $100 \mu \mathrm{g} / \mathrm{ml})$, se ajustaram satisfatoriamente ao modelo linear-quadrático com predomínio do componente linear que foi mais alto em células $\mathrm{CHO}-\mathrm{K} 1$;

- A própolis não influenciou na capacidade clonogênica das células PC3 irradiadas, enquanto que em células $\mathrm{CHO}-\mathrm{K} 1$, teve um leve efeito estimulador da proliferação nas concentrações de 50 e $100 \mu \mathrm{g} / \mathrm{ml}$, nas doses de 2 e 4 Gy. 


\section{REFERÊNCIAS BIBLIOGRÁFICAS}

1. AKAO, Y.; MARUYAMA, H.; MATSUMOTO, K.; OHGUCHI, K.; NISHIZAWA, K.; SAKAMOTO, T.; ARAKI, Y.; MISHIMA, S.; NOZAWA, Y. Cell growth inhibitory effect of cinnamic acid derivatives from propolis on human tumor cell lines. Biological \& Pharmaceutical Bulletin, v.26, n.7, p.1057-1059, 2003.

2. BENKOVIC, V.; KOPJAR, N.; HORVAT KNEZEVIC, A.; DIKIC, D.; BASIC, I.; RAMIC, S.; VICULIN, T.; KNEZEVIC, F.; OROLIC, N. Evaluation of radioprotective effects of propolis and quercetin on human white blood cells in vitro. Biological and Pharmaceutical Bulletin, v.31, n.9, p.1778-85, 2008b.

3. BENKOVIC, V.; ORSOLIC, N.; KNEZEVIC, A. H.; RAMIC, S.; DIKIC, D.; BASIC, I.; KOPJAR, N. Evaluation of the radioprotective effects of propolis and flavonoids in gamma-irradiated mice: the alkaline comet assay study. Biological and Pharmaceutical Bulletin, v.31, n.1, p.167-72, 2008a.

4. BÚFALO, M. C.; CANDEIAS, J. M. G.; SFORCIN, J. M.; In vitro Cytotoxic Effect of Brazilian Green Propolis on Human Laryngeal Epidermoid Carcinoma (HEp-2) Cells. Evidence-Based Complementary and Alternative Medicine, v.6, n.4, p.483-487, 2007.

5. CHEN, C. N.; WENG, M. S.; WU, C. L.; LIN, J. K. Comparison of radical scavenging activity, cytotoxic effects and apoptosis induction in human melanoma cells by Taiwanese propolis from different sources. Evidence-Based Complementary and Alternative Medicine, v.1, n.2, p.175-185, 2004.

6. CHEN, C. N.; WU, C. L.; LIN, J. K. Apoptosis of human melanoma cells induced by the novel compounds propolin A and propolin B from Taiwenese propolis. Cancer Letters, v.245, n.1-2, p.218-231, 2007.

7. DALE, W. M.; GRAY, L. H.; MEREDITH, W. J. The Inactivation of an Enzyme (Carboxypeptidase) by X-Radiation and Alpha-Radiation. Philosophical Transactions of the Royal Society of London Series a-Mathematical and Physical Sciences, v.242, n.840, p.33-62, 1949.

8. DAUGSCH, A.; MORAES, C. S.; FORT, P.; PARK, Y. K. Brazilian red propolischemical composition and botanical origin. Evidence-Based Complementary and Alternative Medicine, v.5, n.4, p.435-441, 2007. 
9. DEAN, B. J.; DANFORD, N. Assays for the detection of chemically induced chromosome damage in cultured mammalian cells, Mutagenecity Testing. In: S. Venitt and J.M. Parry, Editors, A Practical Approach, IRL Press, Oxford, p.187232, 1984.

10.FENECH, M.; MORLEY, A. A. Cytokinesis-block micronucleus method in human lymphocytes: effect of in vivo ageing and low dose X-irradiation. Mutation Research, v.161, n.2, p.193-198, 1986.

11. GARRETT, M. A. Cell cycle control and cancer. Current Science, v.81, n.5, p.515-522, 2001.

12. HALL, E. J. Radiobiology for the radiologist, $5^{\text {th }}$ ed. J.B. Lippincott, Philadelphia, 2000.

13. HARTWELL, L. H.; WEINERT, T. A. Checkpoints - Controls That Ensure the Order of Cell-Cycle Events. Science, v.246, n.4930, p.629-634, 1989.

14. HAVSTEEN, B. H. The biochemistry and medical significance of the flavonoids. Pharmacology \& Therapeutics, v.96, n.2-3, p.67-202, 2002.

15. Hosseinimehr, S. J. Trends in the development of radioprotective agents. Drug Discovery Today, v.12, n.19-20, p.794-805, 2007.

16. HSU, T.; MILLER, C. M.; RIDDER, G. M.; AARDEMA, M. J. Characterization of p53 in Chinese hamster cell lines $\mathrm{CHO}-\mathrm{K} 1, \mathrm{CHO}-\mathrm{WBL}$, and $\mathrm{CHL}$ : implications for genotoxicity testing. Mutation Research-Fundamental and Molecular Mechanisms of Mutagenesis, v.426, n.1, p.51-62, 1999.

17. INSTITUTO NACIONAL DE CÂNCER (INCA) - Ministério da Saúde. Estimativa 2010: incidência de câncer no Brasil / Instituto Nacional de Câncer. - Rio de Janeiro, 2009.

18. INTERNATIONAL ATOMIC ENERGY AGENCY. Cytogenetic analysis for radiation dose assessment. Technical Reports Series, n.405, IAEA, Vienna, 2001.

19. ISHIHARA, M.; NAOI, K.; HASHITA, M.; ITOH, Y.; SUZUI, M. Growth inhibitory activity of ethanol extracts of Chinese and Brazilian propolis in four human colon carcinoma cell lines. Oncology Reports, v.22, n.2, p.349-354, 2009.

20.ITO, J.; CHANG, F. R.; WANG, H. K.; PARK, Y. K.; IKEGAKI, M.; KILGORE, N.; LEE, K. H. Anti-AIDS agents. 48. ${ }^{1}$ Anti-HIV activity of moronic acid derivatives and the new melliferone-related triterpenoid isolated from Brazilian propolis. Journal of Natural Products, v.64, n.10, p.1278-1281, 2001. 
21.JAGETIA, G. C.; BALIGA, M. S. Treatment of mice with a herbal preparation (mentat) protects against radiation-induced mortality. Phytotherapy Research, v.17, n.8, p.876-881, 2003.

22. JEON, S. M.; BOK, S. H.; JANG, M. K.; KIM, Y. H.; NAM, K. T.; JEONG, T. S.; PARK, Y. B.; CHOI, M. S.; Comparison of antioxidant effects of naringin and probucol in cholesterol-fed rabbits. Clinica Chimica Acta, v.317, n.1-2, p.181190, 2002.

23. KASTAN, M. B.; ONYEKWERE, O.; SIDRANSKY, D.; VOGELSTEIN, B.; CRAIG, R. W. Participation of P53 Protein in the Cellular-Response to DNA Damage. Cancer Research, v.51, n.23, p.6304-6311, 1991.

24. KHANNA, K. K.; CHENEVIX-TRENCH, G. ATM and genome maintenance: Defining its role in breast cancer susceptibility. Journal of Mammary Gland Biology and Neoplasia, v.9, n.3, p.247-262, 2004.

25. KHANNA, K. K.; JACKSON, S. P. DNA double-strand breaks: signaling, repair and the cancer connection. Nature Genetics, v.27, n.3, p.247-254, 2001.

26. KIMOTO, T.; KOYA-MIYATA. S.;HINO, K.; MICALLEF, M. J.;HANAYA, T.; ARAI, S.; IKEDA, M.; KURIMOTO, M. Pulmonary carcinogenesis induced by ferric nitrilotriacetate in mice and protection from it by Brazilian propolis and artepillin $\mathrm{C}$. Virchows Archiv, v.438, n.3, p.259-270, 2001.

27. KROL, W.; CZUBA, Z.; SCHELLER, S.; GABRYS, J.; GRABIEC, S.; SHANI, J. Anti-oxidant property of ethanolic extract of propolis (EEP) as evaluated by inhibiting the chemiluminescence oxidation of luminol. Biochemistry International, v.21, n.4, p.593-597, 1990.

28. KUMAZAWA, S.; UEDA, R.; HAMASAKA, T.; FUKUMOTO, S.; FUJIMOTO, T.; NAKAYAMA, T. Antioxidant prenylated flavonoids from propolis collected in Okinawa, Japan. Journal of Agricultural and Food Chemistry, v.55, n.19, p.7722-5, 2007.

29. KUMAZAWA, S.; YONEDA, M.; SHIBATA, I.; KANAEDA, J.; HAMASAKA, T.; NAKAYAMA, T. Direct evidence for the plant origin of Brazilian propolis by the observation of honeybee behavior and phytochemical analysis. Chemical \& Pharmaceutical Bulletin, v.51, n.6, p.740-742, 2003.

30. LEPLEY, D. M.; LI, B., BIRT, D. F.; PELLING, J. C. The chemopreventive flavonoid apigenin induces G2/M arrest in keratinocytes. Carcinogenesis, v.17, n.Il, p.2367-2375, 1996. 
31.LI, F.; AWALE, S.; TEZUKA, Y.; KADOTA, S. Cytotoxic constituents of propolis from Myanmar and their structure-activity relationship. Biological \& Pharmaceutical Bulletin, v.32, n.12, p.2075-2078, 2009.

32.LI, H.; KAPUR, A.; YANG, J. X.; SRIVASTAVA, S.; MCLEOD, D. G.; PAREDES-GUZMAN, J. F.; DAUGSCH, A.; PARK, Y. K.; RHIM, J. S. Antiproliferation of human prostate cancer cells by ethanolic extracts of Brazilian propolis and its botanical origin. International Journal of Oncology, v.31, n.3, p.601-606, 2007.

33. MCVEAN, M.; WEINBERG, W. C.; PELLING, J. C. A p21 (waf1)-independent pathway for inhibitory phosphorylation of cyclin-dependent kinase p34 (cdc2) and concomitant $\mathrm{G}(2) / \mathrm{M}$ arrest by the chemopreventive flavonoid apigenin. Molecular Carcinogenesis, v.33, n.1, p.36-43, 2002.

34.MONTORO, A.; BARQUINERO, J. F.; ALMONACID, M.; SEBASTIA, N.; VERDU, G.; SAHUQUILLO, V.; SERRANO, J.; SAIZ, M.; VILLAESCUSA, J. I.; SORIANO, J. M. Concentration-Dependent Protection by Ethanol Extract of Propolis against gamma-Ray-Induced Chromosome Damage in Human Blood Lymphocytes. Evidence-Based Complementary and Alternative Medicine, p.17, 2011.

35. MORAES, C. S.; DAUGSCH, A.; LI, H.; RHIM, J. S.; PARK, Y. K. Comparative antiproliferation of human prostate cancer cells by ethanolic extracts of two groups of Brazilian propolis. Ciência e Tecnologia de Alimentos, v.30, n.2, p.539-543, 2010.

36. MURAKAMI, D.; SUZUKI, M. F.; DIAS, M. S.; OKAZAKI, K. Genotoxic and cytotoxic effects of ${ }^{60} \mathrm{Co} \gamma$-rays and $90 \mathrm{Sr} / 90 \mathrm{Y} \beta$-rays on Chinese hamster ovary cells (CHO-K1). Radiation and Environmental Biophysics, v.43, n.2, p.91-99, 2004.

37.ORSOLIĆ, N.; BENKOVIĆ, V.; HORVAT-KNEZEVIĆ, A.; KOPJAR, N.; KOSALEC, I.; BAKMAZ, M.; MIHALJEVIĆ, Z.; BENDELJA, K.; BASIĆ, I. Assessment by survival analysis of the radioprotective properties of propolis and its polyphenolic compounds. Biological \& Pharmaceutical Bulletin, v.30, n.5, p.946-951, 2007.

38. ORSOLIC, N.; KOSALEC, I.; BASIC, I. Synergystic antitumor effect of polyphenolic components of water soluble derivative of propolis against ehrlich ascites tumour. Biological \& Pharmaceutical Bulletin, v.28, n.4, p.694-700, 2005.

39.PALAYOOR, S. T.; BUMP, E. A.; CALDERWOOD, S. K.; BARTOL, S.; COLEMAN, C. N. Combined antitumor effect of radiation and ibuprofen in human prostate carcinoma cells. Clinical Cancer Research, v.4, n.3, p.763-771, 1998. 
40. PALAYOOR, S. T.; BUMP, E. A.; TEICHER, B. A.; COLEMAN, C. N. Apoptosis and clonogenic cell death in PC3 human prostate cancer cells after treatment with gamma radiation and suramin. Radiation Research, v.148, n.2, p.105-114, 1997.

41.PARK, Y. K.; ALENCAR, S. M.; AGUIAR, C. L. Botanical origin and chemical composition of Brazilian propolis. Journal of Agricultural and Food Chemistry, v.50, n.9, p.2502-2506, 2002.

42. PARK, Y. K.; IKEGAKI, M. Preparation of water and ethanolic extracts of propolis and evaluation of the preparations. Bioscience Biotechnology and Biochemistry, v.62, n.11, p.2230-2232, 1998.

43.PARK, Y. K.; IKEGAKI, M.; ABREU, J. A. S.; ALCICI, N. M. F. Estudo da preparação dos extratos de própolis e suas aplicações. Ciência e Tecnologia de alimentos. v.18, n.3, p.313-318, 1998.

44.PARK, Y. K.; PASREDES-GUZMAN, J. F.; AGUIAR, C. L.; ALENCAR, S. M.; FUJIWARA, F. Y. Chemical constituents in Baccharis dracunculifolia as the main botanical origin of southeastern Brazilian propolis. Journal of Agricultural and Food Chemistry, v.52, n.5, p.1100-1103, 2004.

45. PISCO, L.; KORDIAN, M.; PESEKE, K.; FEIST, H.; MICHALIK, D.; ESTRADA, E.; CARVALHO, J.; HAMILTON, G.; RANDO, D.; QUINCOCES, J. Synthesis of compounds with antiproliferative activity as analogues of prenylated natural products existing in Brazilian propolis. European Journal of Medicinal Chemistry, v.41, n.3, p.401-407, 2006.

46. PRASAD, S.; NAIK, P.; VIJAYALAXMI, K. K. Efficiency of Coleus aromaticus extract in modifying cyclophosphamide and mitomycin- $C$ induced clastogenicity in mouse bone marrow cells. Indian Journal of Experimental Biology, v.40, n.9, p.1020-1025, 2002.

47.RAO, B. S. S.; SHANBHOGE, R.; UPADHYA, D.; JAGETIA, G. C.; ADIGA, S. K.; KUMAR, P.; GURUPRASAD, K.; GAYATHRI, P. Antioxidant, anticlastogenic and radioprotective effect of Coleus aromaticus on Chinese hamster fibroblast cells (V79) exposed to gamma radiation. Mutagenesis, v.21, n.4, p.237-242, 2006.

48. RITHIDECH, K. N.; TUNGJAI, M.; WHORTON, E. B. Protective effect of apigenin on radiation-induced chromosomal damage in human lymphocytes. Mutatation Research, v.585, n.1-2, p.96-104, 2005.

49. ROSS, J. A; KASUM, C. M. Dietary flavonoids: biovailability, metabolic effects, and safety. Annual Review of Nutrition, v.22, p.19-34, 2002. 
50.RUSSO, A.; CARDILE, V.; SANCHEZ, F.; TRONCOSO, N.; VANELLA, A.; GARBARINO, J. A. Chilean propolis: antioxidant activity and antiproliferative action in human tumor cell lines. Life Sciences, v.76, n.5, p.545-558, 2004.

51.SCOTT, S. L.; EARLE, J. D.; GUMERLOCK, P. H. Functional p53 Increases Prostate Cancer Cell Survival After Exposure to Fractionated Doses of Ionizing Radiation. Cancer Research, v.63, n.21, p.7190-7196, 2003.

52.SCOTT, S. L.; GUMERLOCK, P. H.; BECKETT, L.; LI, Y.; GOLDBERG, Z. Survival and cell cycle kinetics of human prostate cancer cell lines after singleand multifraction exposures to ionizing radiation. International Journal of Radiation Oncology, Biology, Physics, v.59, n.1, p.219-227, 2004.

53. SHIMIZU, K.; DAS, S. K.; HASHIMOTO, T.; SOWA, Y.; YOSHIDA, T.; SAKAI, T.; MATSUURA, Y.; KANAZAWA, K.; Artepillin C in Brazilian propolis induces G0/G1 arrest via stimulation of Cip1/p21 expression in human colon cancer cells. Molecular Carcinogenesis, v.44, n.4, p.293-299, 2005.

54.SHIMIZU, T.; HINO, A.; TSUTSUMI, A.; PARK, Y. K.; WATANABE, W.; KUROKAWA, M. Anti-influenza virus activity of propolis in vitro and its efficacy against influenza infection in mice. Antiviral Chemistry \& Chemotherapy, v.19, n.1, p.7-13, 2008.

55.SHIRAZI, A.; GHOBADI, G.; GHAZI-KHANSARI, M. A radiobiological review on melatonin A novel radioprotector. Journal of Radiation Research, v.48, n.4, p.263-272, 2007.

56. VERMEULEN, K.; VAN BOCKSTAELE, D. R.; BERNEMAN, Z. N. The cell cycle: a review of regulation, deregulation and therapeutic targets in cancer. Cell Proliferation, v.36, n.3, p.131-149, 2003.

57. VIJAYALAXMI; REITER, R. J.; TAN, D. X.; HERMAN, T. S.; THOMAS, C. R. Melatonin as a radioprotective agent: A review. International Journal of Radiation Oncology Biology Physics, v.59, n.3, p.639-653, 2004.

58.WEISS, J. F.; LANDAUER, M. R. History and development of radiationprotective agents. International Journal of Radiation Biology, v.85, n.7, p.539573, 2009.

59. YUHAS, J. M. Efficacy Testing of Wr-2721 in Great-Britain or Everything Is Black and White at the Gray Lab. International Journal of Radiation Oncology Biology Physics, v.9, n.4, p.595-598, 1983. 